\title{
Displaced: Why We Need New International Law to Protect Refugees, Displaced People, and Human Rights
}

\section{Citation}

Goldenziel, Jill I. 2014. "Displaced: Toward a New International Legal Framework for Protecting Refugees and Human Rights." Public Law Research Paper 14-70, Boston University School of Law.

\section{Permanent link}

http://nrs.harvard.edu/urn-3:HUL.InstRepos:27307445

\section{Terms of Use}

This article was downloaded from Harvard University's DASH repository, and is made available under the terms and conditions applicable to Other Posted Material, as set forth at http:// nrs.harvard.edu/urn-3:HUL.InstRepos:dash.current.terms-of-use\#LAA

\section{Share Your Story}

The Harvard community has made this article openly available. Please share how this access benefits you. Submit a story. 


\title{
***DRAFT 8-25-15: PLEASE DO NOT CITE WITHOUT PERMISSION*** \\ DISPLACED: WHY WE NEED NEW INTERNATIONAL LAW TO PROTECT REFUGEES, DISPLACED PEOPLE, AND HUMAN RIGHTS
}

\author{
Jill I. Goldenziel*
}

\begin{abstract}
:
How can international law protect both international security and the human rights of displaced people? Existing international law protects only displaced refugees: those who flee persecution on the basis of religion, race, nationality, or political opinion. This article argues that a new Displaced Persons Convention must be created to protect the human rights of the world's other 35 million victims of civil conflict and climate change who do not meet this narrow definition. International Refugee Law must be preserved as it is because it enshrines critical protections for minority rights that must not be diluted. However, an additional instrument of international law is necessary to resolve an issue that is at once one of the greatest human rights issues of our time and a threat to international peace and security. To support this argument, this article presents a comprehensive history of refugees in international law, combining primary sources and original interview data to trace how states have agreed for centuries that refugee law should protect minority rights, even as shifting state interests have changed refugee protection over time. This article refutes other scholarly proposals and UN practices that expand the category of "refugee." It also contributes to growing scholarly interest in the history of human rights law by arguing that refugee law predates the modern human rights regime, challenges its foundations, and extends its claims to universality.
\end{abstract}

\footnotetext{
* Research Fellow, Harvard Kennedy School, International Security Program, Belfer Center for Science and International Affairs; Visiting Scholar, Fox Leadership Program, University of Pennsylvania. Ph.D., Government, Harvard University; A.M., Government, Harvard University; J.D., New York University School of Law; A.B., Princeton University. Thanks to Susan Akram, Noah Feldman, Rotem Giladi, James Hathaway, James Loeffler, Stanley Katz, Itamar Mann, Michael Pine, Mira Siegelberg, Robert Sloane, Mark Tushnet, and participants in the Boston University School of Law Faculty Workshop and the American Law and Religion Workshop. This article was selected for presentation at the "New Voices in International Law" Panel of the 2015 Annual Meeting of the American Society of International Law.
} 


\section{INTRODUCTION}

"Since the Peace Treaties of 1919 and 1920 the refugees and the stateless have attached themselves like a curse to all the newly established states on earth which were created in the image of the nation-state." ${ }^{1}$ - Hannah Arendt

The plight of refugees and displaced people is the biggest human rights issue of our time. We are bombarded with images of the horrors of displacement, from Syrians and Iraqis fleeing barbarism on foot, to emaciated, battered North Koreans escaped from modern-day concentration camps. As civil conflicts rage on, the problem of population displacement will only worsen. For many, forced displacement means deprivation of the basic legal protections and human rights that states ordinarily guarantee. For rich and poor nation-states alike, refugees remain an ever-worsening "curse" to their professed human rights commitments, their sovereign right to determine who can enter their borders, and even their national security.

But what is a refugee? This question remains highly contested. Doctrinally, international refugee law protects only individuals fleeing persecution on the basis of race, religion, nationality, membership in a particular social group, or political opinion. ${ }^{2}$ No international law is designed to protect the majority of displaced people, who do not meet this definition. As of mid-2014, 13 million people qualified as refugees under international refugee law, while the Office of the United Nations High Commissioner for Refugees (UNHCR) identified 46.3 million people as "persons of concern." 3 An average of 32,000 people per day fled their homes due to violence in 2013, and their harrowing circumstances may or may not qualify them for refugee status. ${ }^{4}$ The reasons for their flight include persecution, generalized violence, economic migration when violence renders their business pursuits unsustainable, and climate-change induced flight from famine or rising seawaters that threaten to wipe entire states off the map. Solutions to the plight of displaced people are complex and heart wrenching, as states struggle to balance their sovereign right to expel aliens from their territory with the reality of dire humanitarian need

${ }^{1}$ HANNAH ARENDT, THE ORIGINS OF TOTALITARIANISM 290 (1973).

${ }^{2} 1951$ Convention Relating to the Status of Refugees, July 28, 1951, 189 U.N.T.S. 137 (hereinafter, "1951 Convention"). 1967 Protocol Relating to the Status of Refugees, Jan. 31, 1967, 606 U.N.T.S. 267 (hereinafter, “1967 Protocol”).

3 UNHCR Global Trends 2013. See also UNHCR report says global forced displacement at 18-year high, UNITED NATIONS HIGH COMMISSIONER FOR HUMAN RIGHTS (June 19, 2013), http://www.unhcr.org/51c071816.html.

${ }^{4}$ UNHCR Global Trends, 2013. 
on their doorsteps. National security concerns, real or imagined, often trump human rights. After all, refugees are people whom states are required to help. Others may legally be returned to hell.

The need for legal reform in this area is urgent. Doctrinal incoherence comes at the cost of human life. Every day, desperate people risk their lives to flee horrific circumstances based on the misperception that they will receive refugee status and resettlement elsewhere. ${ }^{5}$ International and domestic legal and humanitarian infrastructures strain under the sheer numbers of displaced people seeking assistance. Displaced people constantly seek to obtain international refugee status or protection under domestic asylum regimes, overwhelming even the most developed legal systems. In 2014, for example, tens of thousands of unaccompanied minors fled violent conditions in Central America to seek asylum in the U.S. Upon their arrival, the Department of Homeland Security struggled to find enough lawyers and aid workers to meet their needs, amidst highly politicized debate over whether they should be granted legal status as "refugees" or deported as illegal "migrants." Controversies involving the rights of refugees and migrants have reached the highest courts of countries throughout the world, including the U.S. Supreme Court, the High Court of Australia, and the European Court of Human Rights. ${ }^{7}$ These courts' determinations play a major role in shaping the refugee and asylum law of nation-states. Desperate individuals and sovereign states alike need the clarity that international law can provide.

How can international law better protect both displaced people and international security? This article sketches a framework for new international law to address this crucial human rights problem. I argue that existing International Refugee Law, which provides important protections for minority rights, must be preserved. To solve the problem of humanitarian need and international security concerns resulting from other forms of mass displacement, I propose a new Displaced Persons Convention. This Convention would provide a framework for legal

\footnotetext{
5 See, e.g., Luke Mogelson, The IMPossible RefugeE BoAt Lift to Christmas ISLAND, NEW $\quad$ YORK $\quad$ TIMES $\quad$ (Nov. $15, \quad 13$ ) http://www.nytimes.com/2013/11/17/magazine/the-impossible-refugee-boat-lift-tochristmas-island.html?pagewanted=all.

${ }^{6}$ See Frances Robles, Fleeing Gangs, Children Head to U.S. Border, New York TIMES (July 9, 2014) http://www.nytimes.com/2014/07/10/world/americas/fleeing-gangschildren-head-to-us-border.html.

${ }^{7}$ See, e.g., Sale v. Haitian Centers Council, 509 U.S. 155 (1993); Ruddock v. Vadarlis (2001) FCA 1329 (Federal Court) (Austl.); Hirsi Jamaa and Others v. Italy, 2012 Eur. Ct. H.R.; M.S.S. v. Belgium and Greece, 2011 Eur. Ct. H.R.; for discussion of these cases, see Jill Goldenziel, When Law Migrates: Refugees in Comparative International Law (forthcoming).
} 
protection for individuals who have fled generalized violence, natural disasters, and other events deemed by the international community to threaten international peace and security. These reforms would improve protections for refugees, displaced people, and states alike by clarifying who should receive international protection. It would also buttress other major goals of international human rights law, such as religious freedom, freedom of expression, and protection against racial discrimination. ${ }^{8}$ The improved doctrinal clarity would help shape the behavior of both states and individuals in the international system and present a stronger, less politicized, legal framework for humanitarian burden-sharing by the international community.

The historical record supports this normative argument. By tracing the history of refugees in international law, I explain how the changing interests of states have shaped how the term "refugee" has been defined over time. In doing so, I isolate the core of what states have consistently sought to protect through refugee status: the rights of dissidents and especially minorities. Understanding the history of international refugee law, including the political context in which it developed, supports the creation of new international law for refugees and displaced people appropriate for the current era. The normative solution presented is both realist in its goal of protecting state interests and liberal in its appeal for an international legal solution to protect international peace and security and human rights.

This historical account also challenges current scholarly debates about human rights. Most historical and social science literature on human rights regards the great "constitutional moment" in the immediate aftermath of World War II, as the birth of international human rights law. ${ }^{9}$ Other scholars situate this moment later, when transnational human rights activism became more visible in the $1970 \mathrm{~s} .{ }^{10}$ My account, however, reveals that the roots of human rights law - in the sense of universal, liberal rights that should be enjoyed by people regardless of where they live-are much

\footnotetext{
8 Convention on the Elimination of Racial Discrimination, Dec. 21, 1965, 660 U.N.T.S., 195; International Covenant on Civil and Political Rights, Dec. 16, 1966, 999 U.N.T.S. 171, Art. 18.

${ }^{9}$ The term "international constitutional moment" is borrowed from William W. BurkeWhite \& Anne-Marie Slaughter, An International Constitutional Moment, 43 HARV. INT'L L.J. 1 (2004). Although Slaughter and Burke-White primarily focus on humanitarian law, the concept has been applied to the birth of international human rights law as well.; see also Elizabeth Borgwardt, A New Deal for the World (2007); B. A Simmons, MobiLizing FOR Human Rights: InTERnATIONAL LAW IN DOMESTIC Politics,(2009) (tracing the dawn of human rights to the same historical moment in the wake of WWII).

${ }^{10}$ E.g., Samuel Moyn, The Last Utopia: Human Rights in History (2010).
} 
deeper. ${ }^{11}$ Discussion of the need for the protection of refugees under international law is at least as old as the modern Westphalian nation-state, and the concept of protecting those fleeing persecution has roots in all of the world's major religious legal traditions..$^{12}$ International refugee law was among the first major human rights projects of the fledgling United Nations. The 1951 Convention Relating to the Status of Refugees (the "1951 Convention") developed in the same historical moment as the Universal Declaration of Human Rights and the Genocide Convention, and for similar reasons, as the recovering world sought to ban the atrocities perpetuated by the Nazis. While scholars of international law and international relations have paid far less attention to the history of the 1951 Convention than that of other human rights instruments, such as the International Covenant on Civil and Political Rights (ICCPR) and the International Covenant on Economic and Social Rights (ICESCR), the 1951 Convention far preceded them, entrenched and enhanced prior state practice, and was the first human rights instrument to legalize many of the same rights found in these later documents. My account thus adds to current scholarly debates and our evolving understanding of the origins and development of human rights in international law.

The article will proceed in four parts. Part I will explain why many previous scholarly accounts of the development of international human rights law have largely ignored international refugee law, and why it is critical for this gap in the literature to be rectified. Part II will trace the history of the international refugee regime. This account aims to add refugee law to other major accounts of the origins of international human rights law. ${ }^{13}$ Because refugee rights encapsulate the international

${ }^{11}$ As Moyn suggests, the definition of what constitutes human rights has changed over time. Id. My aim here is to trace the roots of human rights in the liberal, cosmopolitan sense in which they are now commonly understood, while acknowledging that the concepts of human rights and refugee status may have had different significance for states and individuals at other points in history.

${ }^{12}$ Discussion of the roots of the concept of asylum in both the Hebrew Bible and in Ancient Greece can be found in . On the Islamic roots of asylum, see e.g.,AHMED ABOUEl-WAFA, The Right to ASYlum BetweEn ISLAMiC SHARI'AH AND INTERNATIONAL REFUGEE LAW: A COMPARATIVE STUDY (2009).

${ }^{13}$ In a four-page piece, Louis Henkin called for the integration of refugee law and human rights law, but had little space to build an argument as to why. Louis Henkin, Refugees and their Human Rights, 18 FORDHAM INT'L L.J. 1079, 1079-81(1994) (noting "It is time to bring the international law of refugees and the international law of human rights together.") James Hathaway and Guy Goodwin-Gill have made earlier calls to rethink refugee law as human rights law, and I aim to build on their accounts with additional theory and new historical and contemporary data. See generally James C. Hathaway, Reconceiving Refugee Law as Human Rights Protection, 4 J. REFUG. STUD. 113-131

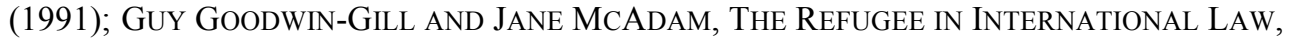


community's commitment to minority rights, no understanding of the history of international human rights law can be complete without this account. Part III explains why the current international refugee regime has failed to protect refugees, displaced people, and state interests. Part IV argues that the 1951 Convention and its 1967 Protocol must be preserved to protect minority rights, but that an additional Displaced Persons Convention is also necessary. After sketching what a Displaced Persons Convention might look like, I will conclude with some implications for what this analysis implies for our understanding of international human rights law overall.

\section{REFUGEE Rights As HuMAN Rights}

Most previous scholarly treatments of human rights, in both historical and social science literature, have presented one of three versions of human rights history. Two concern themselves with the great "constitutional moment" of international law, and international human rights law in particular, that followed the end of the Second World War. Historian Mark Mazower aptly terms these two approaches the "Eleanor Roosevelt version" and the "Hitler version."14 In the Eleanor Roosevelt version, international human rights law developed due to the heroic actions of individuals, including Hersh Lauterpacht, Raphael Lemkin, and Roosevelt herself. ${ }^{15}$ In the "Hitler version," states collectively reeled from the horrors of the Nazis and galvanized to proclaim "never again." 16 A third narrative, associated with historian Samuel Moyn, submits that human rights as we know it actually began only in the 1970s, when large-scale transnational activism and the convergence of previous rights movements for discrete groups brought a global consciousness of we now know as "human rights." 17

All of these versions, while cataloguing remarkable achievements of individuals and states, are incomplete. All three versions largely dismiss the historical development of international human rights and transnational activism for them prior to World War II, although nations had begun to give serious thought to the basic rights to which all people are entitled, regardless of nation-state borders. The Hitler and Roosevelt versions, in their triumphalism of individual rights, do not give sufficient consideration

3D ED. (2007).

14 Mark Mazower, The Strange Triumph of Human Rights, 1933-1950, 47 Hist. J. 379, 380 (2004).

${ }^{15}$ See BORGWARDT, supra note 9

${ }^{16}$ SimMONS, supra note 9.

${ }^{17}$ See generally MoYN, supra note 10. 
to the state interests that shaped the development of the international human rights regime. ${ }^{18}$ As Mazower explains, individuals such as Roosevelt and Lemkin were only able to succeed because states let them. Moreover, he notes, the "constitutional moment" was not initially experienced as such, since the full extent of the Nazi horrors had not yet been revealed. As he explains, "we now know that the Holocaust as such was much less central to perceptions of what the war had been about in 1945."

Finally, all three of these versions largely ignore international refugee law in their analyses. Scholars have largely analyzed international refugee law as doctrinally distinct from international human rights law. ${ }^{19}$ Scholars of international law and international relations - lawyers, political scientists, and historians alike - largely ignore international refugee law in their accounts. ${ }^{20}$ Major legal casebooks on international human rights law give short shrift to international refugee law, if they cover it at all. ${ }^{21}$ Meanwhile, scholars of refugees often do not concern themselves with broader issues of human rights. Scholarship from the field of refugee studies, such as excellent work by Alexander Betts and James Milner, largely concern themselves with refugee policy in practice and the operation of the Office of the United Nations High Commissioner for Refugees (UNHCR). ${ }^{22}$ Louis Henkin and James Hathaway, arguably the most important living scholar of refugees in the American legal academy, have both called for the integration of the refugee and human rights regimes, but stop short of providing a full theoretical account of how and why to do so. ${ }^{23}$

${ }_{19}$ See Mazower, supra note 14, at 381.

19 See, e.g., Henkin, supra note 13, at 1079-81 (recognizing the usual doctrinal separation between the two regimes).

${ }^{20}$ See, e.g., SimMONS, supra note 9; Emilie Hafner-Burton and Kiyoteru Tsutsui, Justice Lost! The Failure of International Human Rights Law to Matter Where Needed Most, 44 J. PEACE RESEARCH 4, 407-425 (2007); Eric Neumeyer, Do International Human Rights Treaties Improve Respect for Human Rights? 46 J. CONFLICT RESOLUTION 6, 92553 (2005), Oona Hathaway, Do Human Rights Treaties Make a Difference? 111 YALE L.J. 1870 (2002); Linda Camp Keith, The United Nations International Covenant on Civil and Political Rights: Does it Make a Difference in Human Rights Behavior?, 36 J. PEACE RESEARCH 1, 95-118 (1999). Only Koh (1997), gives international refugee law a brief mention.

${ }^{21}$ See, e.g., Henry Steiner, Philip Alston \& RyAn GOODMAN, InTERnAtional HUMAN RIGHTS IN CONTEXT: LAW, POLITICS, MORALS: TEXT AND MATERIALS (2008) (omitting mention of international refugee law).

${ }^{22}$ Alexander BetTs, Protection By PERSUASION: INTERNATIONAL COOPERATION IN THE REFUGEe REGIME (2009); AleXANDER BETTS, Gil LOESCHER AND JAMES Milner UNHCR: The Politics and Practice of Refugee Protection (2012); Gil Loescher, Alexander Betts \& James Milner, The United Nations High Commissioner for REFUGEES (UNHCR): THE POLITICS AND PRACTICE OF REFUGEE PROTECTION INTO THE TWENTY-FIRST CENTURY (2008).

${ }^{23}$ See Hathaway, supra note 20. Oxford refugee scholar Guy Goodwin-Gill, too, 
Overall, refugee law remains misunderstood as a key element of international human rights law, although its framers were deeply concerned with protecting human rights.

\section{A. Why is Refugee Law Ignored by Human Rights Law Scholars Today?}

Perhaps this scholarly omission has occurred because of the distinct features of refugee law that differentiate it from other forms of human rights law. International refugee law implicates sovereignty, security, and political concerns that are unique to the human rights regime. International human rights law was carefully designed not to conflict with the principle of state sovereignty. Human rights treaties bind states to provide certain rights to their own citizens, at least in theory. States' commitment to multilateral human rights treaties implies that the international community has an interest in protecting the human rights of citizens of other states. ${ }^{24}$ In practice, however, human rights treaties suffer from a notorious lack of enforcement. States are largely unwilling to intervene in the affairs of other states to protect against human rights violations. The U.N. Secretary General's 2012 report on the Responsibility to Protect names only four circumstances in which humanitarian intervention is justified to protect the citizens of other states against human rights violations: genocide, war crimes, ethnic cleansing, and crimes against humanity. ${ }^{25}$ States have been hesitant to violate state sovereignty for even these dire abuses. Many champions of human rights law believe it will lead to a moral utopia where all can enjoy equal rights and freedoms wherever they may live. ${ }^{26}$ However, states, thus far, have dictated a vastly different reality.

International refugee law, by contrast, implicates state sovereignty in an important way that other international human rights treaties do not. At the core of international refugee law lies the jus cogens norm of nonrefoulement, from which no state can derogate. Non-refoulement effectively

defines refugee rights as human rights. See generally GUY GOODWIN-GILL AND JANE MCAdAm, The REFUGEe In InTERnAtional LAW (2007). Refugee scholars, and human rights lawyers more generally, equate refugee rights with human rights. However, as a doctrinal matter, in the American legal and social science academies, study of the 1951 Refugee Convention has been ignored in studies of human rights treaties. See, e.g., generally, Eric Posner, THE TWILIGHT OF HuMAN Rights LAW (2014) (listing human rights present in all major human rights treaties except the Refugee Convention).

${ }^{24}$ Jill I. Goldenziel, Regulating Human Rights: International Organizations, Flexible Standards, and International Refugee Law, 14 CHI. J. INT'L. L. 453-702 at 488 (2014).,

25 United Nations Secretary-General, Secretary-General's 2009 Report on Implementing the Responsibility to Protect, A/63/677.

${ }^{26}$ For an enthusiastic take on the global spread of human rights through law, see generally KATHRYN SIKKINK, THE JUSTICE CASCADE (2011) (discussing how "the justice norm" of prosecuting leaders for human rights abuses has spread globally). 
binds states to keep within their borders anyone who might be endangered if sent back to their country of origin. ${ }^{27}$ To be in compliance with international refugee law, then, signatory states must not summarily return anyone who meets the Convention definition of refugee to his country of origin. International refugee law conflicts with the basic right of a sovereign state to expel aliens from within their borders, and demands that states accord certain rights to non-citizens. Compliance with the 1951 Convention has thus created economic burdens and security issues for signatory states. The U.S., Europe, and Australia, for example, have built a massive system of detention centers to house asylum-seekers who arrive within their borders until they can be processed to determine whether they are refugees.

In countries with less secure borders, particularly in the Global South, refugees have posed domestic security threats to their host countries as well as international security risks. Without social and legal protections in their host countries, and with their previous social order destroyed, refugees have formed in-group networks for welfare provision or to compete for resources within their new environment. These networks provide an alternate source of political authority to the state, and potentially a threatening one in weak states. Refugees have used camps as a locus to mobilize co-ethnics or co-group members against their countries of origin their new host states. ${ }^{28}$ In some circumstances, host countries have used refugees to destabilize their countries of origin, as occurred in the Great Lakes Region of Africa in the 1990s. ${ }^{29}$ Refugee communities may host rebel groups, as Syrian exiles have in Turkey since the Syrian civil war. Host states may be unable to contain militant refugees, some of who may be receiving protection and assistance inadvertently provided by international humanitarian agencies. For example, in refugee camps in Burundi and Tanzania in the 1990s, the UN Refugee Agency inadvertently provided assistance to Hutu rebels, who later returned to Rwanda to commit genocide. ${ }^{30}$ International refugee law demands that states put themselves at

\footnotetext{
${ }^{27}$ The majority view among highly qualified publicists and commentators is that nonrefoulement has attained the status of jus cogens despite some state practice to the contrary. See Jean Allian, The Jus Cogens Nature of Non-Refoulement, 13 INT'L J. REFUGEE L. 4, 533, 558 (2001); Walter Kälin et al., Article 33, Para. 1, in THE 1951 CONVENTION RELATING TO THE STATUS OF REFUGEES AND ITS 1967 PROTOCOL: A COMMENTARY 1327, 1347-49 (Andreas Zimmermann ed., 2011).

${ }^{28}$ See generally Idean Salehyan, The Externalities of Civil Strife: Refugees as a Source of International Conflict, 52 AM. J. POL. SCI., 787-801 (2007).

29 See generally Idean Salehyan, Transnational Rebels: Neighboring States as Sanctuary for Rebel Groups, 59 WORLD POLITICS 217-242 (2008); SARAH KENYON Lischer, Refugee CAmps, Civil War, And THE Dilemmas of Humanitarian Aid (2006).

${ }^{30}$ See generally LISCHER, supra note 29.
} 
risk in order to accept persecuted people, even if they are a potential security threat. International human rights law places no such burden on a state's domestic security; indeed, most believe that a state's compliance with international human rights law will only improve domestic complacence.

International refugee law also serves a political function for states that human rights law does not. As Matthew Price has argued, countries' ability to grant asylum, as expressed in international refugee law, plays a critical expressive function in international politics. ${ }^{31}$ A state's ability to determine a citizen of another state to be a "refugee" enables one state to sanction another within the international system. Classifying a citizen of another state as a "refugee" enables a state to express judgment about the morality of the state of origin or its abuse of authority in a particular circumstance. In 2013, the case of Edward Snowden illustrated this function. By offering Snowden temporary asylum, Russia and Ecuador played a political card against the U.S., expressing disdain about its invasive data-gathering policies. Human rights law, too, serves an expressive function, as states have used the language of law to condemn human rights abuses abroad. However, the expressive function of refugee law is accompanied by a more powerful expressive action. By physically accepting a refugee from another state, a state goes beyond rhetoric to intervention into another state's affairs. A host state may also be able to use that refugee strategically, to speak out and rally others against his country of origin, or to gain intelligence on rights abuses or operations there. This expressive function served an especially important purpose during the Cold War, when the U.S. and its allies granted refugee status in large numbers to defectors from the Soviet Union and Eastern Europe.

On a philosophical level, international refugee law poses a challenge to the fundamental assumptions underlying human rights law. Human rights law posits that sovereign states are the guarantors of human rights; and thus, supposes that human rights are bounded by membership in a particular political community or tied to a particular territory. As Giorgio Agamben explains, politics itself is a constant process of inclusion and exclusion; of determining whom the sovereign will protect and whom it will not. ${ }^{32} \mathrm{~A}$ refugee, then, is the exemplar par excellence of this political process. Refugee status begins when a sovereign decides not to or fails to protect an individual's human rights to the point that the individual is compelled to

\footnotetext{
${ }^{31}$ MAtTHew PRice, RethinKING ASYlum 24-57 (2009).

32 See generally Giorgio Agamben, Homo SACER (1998); see also Prem Kumar Rajaram and Carl Grundy-Warr, The Irregular Migrant as Homo Sacer: Migration and Detention in Australia, Malaysia, and Thailand, 42 InT'L Migration 1 (2004), 33-64, at 34.
} 
disassociate himself completely from the sovereign. International refugee law presents a challenge to human rights law - and to the very notion of sovereignty-by suggesting that humans have rights independent of a sovereign. International refugee law is an acknowledgment that rights exist outside the state, and thus a threat to the concept of the benefits of sovereignty: a refugee may have more human rights outside of an oppressive state than within it. International refugee law both implies that human rights exist outside the sovereign and that when states cannot provide those human rights to their own citizens, other states are bound to provide a substitute, thereby infringing on their own sovereignty. This leads to a dilemma that may explain a doctrinal divide: if the human rights regime is based on the premise of a sovereign who can guarantee those rights, then rights that exist without a sovereign to guarantee them must be something outside of that human rights regime.

\section{B. Why Refugee Law Should Be Considered Human Rights Law}

Thus, for important doctrinal reasons, scholars have largely viewed international refugee law as doctrinally separate from human rights law. Yet, an understanding of refugee law is critical for our understanding of international human rights law. The concerns of international refugee law speak to the primary interests of anyone who cares about human rights. In an era when sovereignty being questioned by scholars and states and challenged by non-state actors, it is worth considering what human rights the international community considers to be beyond the pale of sovereignty. Refugee status begins when a sovereign state fails, by choice or otherwise, to protect the human rights of its citizens. If we believe that rights exist beyond and outside of the state, human rights lawyers must care about refugee rights.

To the extent that human rights law and liberal democracy are linked-and most believe that they are-refugee law is even more important. The protection of minorities has long been a sine qua non of liberal democracy. ${ }^{33}$ In Michael Walzer's words, individual assimilation and group recognition, by liberating either individuals or groups from persecution, are "the central projects of modern democratic politics." ${ }^{34}$ If liberal democracy is the normative model for states in the international community, then the UDHR, ICCPR, and ICESCR comprise the world's model bill of rights. All of these instruments demand that sovereign states

${ }^{33}$ See generally JOHN HART ELY, DEMOCRACY AND DISTRUST: A THEORY OF JUDICIAL REVIEW (1980).

${ }^{34} \mathrm{Id}$., at 84 . 
provide rights to their citizens. Refugee law, then, must complement this bill of rights to ensure protection of minorities and dissidents who exist outside of sovereign protection. Otherwise, they would become, to use Hannah Arendt's term, "rightless." "35 Arendt argues that refugees, minorities, and stateless people were rightless after World War I because they were not members of any polity that could grant them rights, and thus put the lie to the idea of the universality of the Rights of Man. International refugee law, then, came after World War II to remedy this rightlessness. International refugee law demands that states respect the human rights of such individuals and affirm their own commitment to the goals of human rights law. As the international community's normative commitment to democracy has increased, and the plight of minorities has continued to worsen, minority rights must continue to be a paramount concern. ${ }^{36}$ An international legal system that gives short shrift to refugee rights is not truly concerned about human rights. If human rights are inalienable, they cannot be dependent on a sovereign, and ensuring rights for those whom the sovereign will not protect is of crucial importance.

The protection of religious, ethnic, racial, and national minorities to whom nation-states cannot or will not provide legal protections was among the first great projects of international law. Current international refugee law represents the international community's attempt to improve upon its past failures to protect the rights of minorities and political dissidents. Adding the history of international refugee law to previous accounts of human rights law both illuminates how state interests shaped the human rights regime and reveals how critical thinkers and actors in the human rights movement viewed the meaning of human rights. Placing the story of refugee law against the backdrop of what we know about human rights law also informs our understanding of how the refugee regime was meant to function. Previous accounts of both regimes are incomplete without an understanding of the other.

\section{THE Historical DEVELOPMENT OF INTERNATIONAL REFUGEE LAW}

The definition of "refugee" in international law has evolved to reflect state interests. In the early era of international refugee law, powerful states largely determined who received refugee status. As the law developed, state practice became a source of law, and early categories created by European states took on a precedential character. The current

\footnotetext{
${ }^{35}$ HANNAH ARENDT, ON THE ORIGINS OF TOTALITARIANISM, at 268.

${ }^{36}$ U.N. Charter Arts. 3-6; EC Membership requirements.
} 
definition of "refugee" was created by Western states. However, state practice in the developing world, particularly more lenient definitions of "refugee" in regional legal instruments in Africa and Latin America, have also influenced the development and implementation of international refugee law far beyond European borders.

The development of international refugee law reflects the international community's turn from protection of group rights to protection of individual human rights. Early definitions of the refugee in international law were created in response to the perceived needs of states to provide protection for groups of refugees fleeing from specific states whose policies warranted international condemnation. As ad hoc treaties protecting different groups of people caused inconsistencies in implementation, and states became overwhelmed with increasing flows of refugees, states saw the need to restrict the definition of refugee. When the interwar Minority Rights Treaties failed and the post-World War II rights dialogue shifted from protection of group rights to individual rights, refugee law followed suit, reflecting a new concept of individual persecution compatible with the needs of states and individuals alike. ${ }^{37}$ The historical record reveals why international refugee law may have been satisfactory for the needs of states and individuals at the time it was developed, but is deeply flawed in the post-Cold War, post-9/11 context.

\section{A. Pre-Westphalian Freedom from Persecution}

Among the first great international legal projects was the protection of minorities and persecuted people. Because human rights scholars have focused on human rights law's development in the wake of World War II, it is often forgotten that the international community endeavored to protect the rights of minorities and other persecuted people long before. ${ }^{38}$ The concepts of refuge and refugees predate the modern nation-state. The term has always referred to fleeing people. In the course of history, it has often referred to those fleeing religious persecution, and refuge has often been granted on religious grounds.

The concept of asylum has roots in most of the world's major

${ }^{37}$ While the Minority Rights Treaties were concerned with minority rights in the interwar sense of preserving the peace in Europe by ensuring basic human rights for ethnic minorities and stateless people, there is no doubt that they were concerned with providing international protection for minorities within Europe. While acknowledging the historical difference in usage of the term "minority," this article treats the Minority Rights Treaties as a stepping-stone toward future legalization of international protection for members of minority groups in the modern, liberal-democratic sense.

${ }^{38}$ See Slaughter \& Burke-White, supra note 9. 
religions, although those to whom it would be granted varied according to cultural practices. ${ }^{39}$ In the Hebrew Bible, cities where manslaughterers could flee persecution became known as "cities of refuge." ${ }^{\text {"In }}$ In the history of state warfare, the concept of asylum dates at least as far back as the Peloponnesian War, when Athenians and Spartans alike granted refuge in their own religious temples to those fleeing persecution. ${ }^{41}$ The English term "refuge" dates back to 1350-1400. Derived from Middle English, Middle French, and Latin, it is related to the word refuge(ere), which meant "to turn and flee, or run away." 42 The French "réfugié" was first used in 1573 to refer to Calvinists fleeing what is now Belgium, then under Spanish Catholic rule. ${ }^{43}$ The English term "refugee" dates from 1675-85, derived from the French, reflecting Protestant flight leading up to the 1685 revocation of the Edict of Nantes. ${ }^{44}$

By the time the term had come into use, religious minorities were routinely under assault in Europe. Rulers justified expulsion projects on religious grounds and goal of building national homogeneity. To choose but one prominent example, Spain expelled Jews from its territories in 1492, followed by Protestants from 1577 through the 1630s, and Moors in 1609. After trying to forcibly convert their Jewish population, the Aragons eventually decided that the political necessity of forming a modern nation justified the cost of expelling an important economic class and at least 2 percent of their population. ${ }^{45}$ Figures of those expelled vary, but range from tens of thousands to $200,000^{46}$ After some fled to Portugal and quickly met expulsion there, Jews and converted Jews dispersed throughout Southern Europe, the enemy Netherlands, and the Ottoman Empire. Only the

39 See Ahmed Abou-El-Wafa, The Right to Asylum between Islamic Shari'ah and International Refugee Law: A Comparative Study, UNHCR (2009)..

${ }^{40}$ On cities of refuge, see Deuteronomy 3:23-7:11. These biblical cities of refuge ('ir miklat) are often cited as the roots of the concepts of refuge and asylum. See, e.g., Price at - ${ }^{\prime}{ }_{41}$

41 See ThuCydides, History OF THE PELOPONNESIAN WAR.

${ }^{42}$ RANDOM House Dictionary OF THE ENGLISH LANGUAGE.

${ }^{43}$ Aristide Zolberg, The Roots of American Refugee Policy, 55 Social Research 649678 (1988), at 651.

${ }^{44}$ Random House Dictionary of the English LANGUAGE; See also Id; Haddad at 55.

${ }^{45}$ Egger estimates tens of thousands. Zolberg estimates that 120,000-150,000 Jews were expelled, which would amount to $2 \%$ of the Spanish populationFranco estimates the number at 200,000. See Egger at 82; Zolberg, at 31; Moise Franco, Essai sur l'histoire des Israelites de I'empire Ottoman depuis les origines jusqu'a nos jours (Paris, 1897; repr. Hildesheim, 1973), pp. 37-8

46 Cited by Kamen: Moise Franco, Essai sur l'histoire des Israelites de I'empire Ottoman depuis les origines jusqu'a nos jours (Paris, 1897; repr. Hildesheim, 1973), pp. 378. Baer, Historia de los judios, ii, at 650 
Ottomans welcomed the Jews with open arms after a proclamation from Sultan Bayezid II gave orders to do so. ${ }^{47}$ According to historian Bernard Lewis, Jews were welcome because they were an "economically active and politically reliable element." 48

Despite having large numbers of persecuted minorities, European states did not find it necessary to create formal international law that specifically protected refugees in the fifteenth through nineteenth centuries. ${ }^{49}$ Multilateral treaties protecting human rights or individual rights, in general, were uncommon in this period. European states that produced and accepted refugees were occupied with territorial conquest and consolidation of states and empires. States responded to refugees on an ad hoc basis, and enacted few restrictions to entry. The prohibitive cost of transport meant that refugees were largely wealthy, and states welcomed them as contributors to their economies. Refugees, by and large, entered as individuals and not en masse, and caused few problems for state security.

\section{B. Pre-WW I Legal Protections for Minorities}

International law has been concerned with protecting minorities and refugees at least since the Treaty of Westphalia in $1648 .{ }^{50}$ Religious and ethnic minorities remained a large political obstacle to the goal of congruity between nation and state. The Treaty introduced the legal concept of jus emigrandi: individuals who faced religious persecution had the right to leave their state of origin and seek sanctuary elsewhere. ${ }^{51}$ The Treaty did not, however, require states to provide asylum. In some cases, states could not control their borders and had no choice but to accept refugees. Other states would choose to provide asylum for varied reasons: out of humanitarianism, to support co-religionists, to cast aspersion on other states, or to add wealthy, skilled immigrants to their citizenry. These objectives would often overlap.

Jus emigrandi soon had its first test. In 1685, 200,000 Protestants fled France after King Louis XIV revoked the Edict of Nantes, which had protected Protestants from persecution since 1598, when many were fleeing the Inquisition. ${ }^{52}$ Prussia, in particular, welcomed these Huguenots due to

${ }^{47}$ Egger, at 82; BERNARD LEWIS, CULTURES IN CONFLICT (1995), at 38.

${ }^{48}$ LEWIS, id., at 43-44.

49 James C. Hathaway, The Evolution of Refugee Status in International Law: 19201950, 33 INT. COMP. LAW Q. 348 (1984).

${ }^{50}$ On the limits of the Westphalian State, see Stephen Krasner, Compromising Westphalia, 20 INT'L SEC. 3, 115-51 (1996).

${ }^{51}$ Phil Orchard, A Right to Flee: Refugees, States, and the Construction of INTERNATIONAL COOPERATION (2014), at 45.

${ }^{52}$ Laura Barnett, Global Governance and the Evolution of the International Refugee 
religious affinity. ${ }^{53}$ Their relatively wealthy status could not have hurt their cause. This was, perhaps, the first modern refugee movement: it was a mass movement in an era of nation-states based on religious persecution in a time of relative peace. ${ }^{54}$

As early as 1789, refugee flows were playing an important role in international politics and causing international security concerns. State building and nationalism were twin goals of the era. States used mass population displacements as a tool for creating national and state identity. Large numbers of persecuted dissidents fled the French Revolution. Refugees helped to shift the balance of power in Europe as they fled to Austria, Prussia, Russia, and England. ${ }^{55}$ These states were willing to offer refuge to cast aspersion on the new France and its hegemonic goals. The building of unified nation-states in 1848 then led to the sometimesdeliberate expulsion of thousands of refugees from Italy, Germany, and France. ${ }^{56}$ For example, 80,000 Germans were expelled from France because of the wars of German unification. 130,000 people who "considered themselves French left Alsace-Lorraine under the Treaty of Frankfurt in 1871.. ${ }^{, 57}$ Despite these large numbers, most population flows were much smaller than they are today. Host states continued to welcome those refugees who were skilled and wealthy.

By the Revolutions of 1848, it became clear that some dissidents posed security threats, and entry restrictions began to develop. ${ }^{58}$ A set of British "Alien Acts" in 1793, 1796, and 1844 created limits and regulations on who could enter the country; the 1905 Alien Act differentiated between refugees (the few, persecuted individuals) and immigrants (the poor and many). ${ }^{59}$ England and Switzerland continued to accept large numbers of refugees, developing reputations as hotbeds for revolutionary exiles and causing political tensions with France and Austria. ${ }^{60}$ The need for an international system to protect both persecuted individuals and international security was becoming necessary.

While international law to protect persecuted people did not yet exist, states were beginning to lay its groundwork by the nineteenth century. A patchwork body of international legal protections for aliens began to

Regime, 14 INT'L J. REFUGEE L. 238, 239 (2002).

${ }^{53} I d$. at 240.

${ }^{54}$ Zolberg? Haddad?

${ }^{55}$ Barnett, supra note 52, at 241; see also Cecilia Ruthstrom-Ruin, BEYOND EUROPE:

The Globalization of RefUgeE Aid 15 (1993).

${ }^{56}$ Haddad 56

${ }^{57}$ Haddad 55

${ }_{58}^{58}$ Barnett, supra note 52, at 241.

${ }^{59}$ Haddad 55

${ }^{60} I d$. 
develop, which can be viewed as the precursor to modern refugee law. Encompassed in treaties of "friendship, commerce, and navigation," certain human rights, phrased then as "human dignities," were granted to aliens living in trading states. ${ }^{61}$ The treaties were meant to ensure that aliens did not face discrimination when they engaged in legal commercial activity and received access to judicial systems. The rights included recognition of juridical personality, respect for physical integrity, and personal and religious freedom, but not political rights. ${ }^{62}$ These rights were widely recognized as general principles of international law. States would enforce these rights by lodging a claim in support of their own nationals, so such law did not directly benefit refugees ${ }^{63}$ However, the development of these general principles of law represented a breakthrough in international law because the treaties granted rights to citizens outside of the borders of their states, implicitly acknowledged their intrinsic vulnerability, and recognized that international protections for them were necessary. ${ }^{64}$

\section{Interwar Minority Protection Efforts}

After World War I, the issue of minority and refugee protections became urgent. With the collapse of the great empires, the homogeneity of nation-states became a political goal once more, and the existence of minority groups resurfaced as a dilemma. The European powers feared that the large numbers of foreign nationals displaced within Europe threatened to cause another international conflict. At the Versailles peace conference, all successor states to the Ottoman and Hapsburg empires were forced to sign Minority Rights Treaties in order to receive state recognition by the international community. ${ }^{65}$ The League of Nations was charged with enforcement of the treaties. The goal of these Minority Rights Treaties was to protect Eastern European minorities, particularly Jews, from persecution in the states where they lived. The treaties guaranteed religious, linguistic, racial, and national minorities rights equal with the nationals of the states where they resided, access to public employment, language rights, public funding, and also the right to maintain their language and cultural

${ }^{61}$ JAMES C. HATHAWAY, THE RIGHTS OF REFUGEES UNDER INTERNATIONAL LAW 76 (2005) ; also see A. Roth, THE Minimum STANDARD Of INTERNATIONAL LAW APPLIED TO ALIENS (1949).

${ }^{62}$ HathaWAY, supra note 61 , at 76-77.

${ }^{63} \mathrm{Id}$. at 79 .

${ }_{65}^{64} \mathrm{Id}$.

${ }^{65}$ On Minority Rights Treaties, see Nathaniel Berman, "But the Alternative Is Despair": European Nationalism and the Modernist Renewal of International Law, 106 HARV. L. REV. 1792, 1792-1903 (1993). For discussion of these treaties in their historical context, see also Mazower, supra note 14. 
institutions. ${ }^{66}$ The major powers hoped that granting these rights to minorities would help to avert another major international conflict. From a legal perspective, the Treaties represented recognition that millions of people were not protected by the ordinary laws of their states, and needed an international guarantor to ensure their basic rights. ${ }^{67}$

Early instruments of international law were developing on an ad hoc basis to protect dissidents and minorities. After the Russian Revolution, more than 1 million people flooded into Europe between 1917 and $1921 .^{68}$ Some fled from famine and overall destruction of their communities, while others were persecuted by the Bolshevik regime.$^{69}$ Many of these Russians had their citizenship revoked, creating one of Europe's first major crises of statelessness. ${ }^{70}$

The nascent League of Nations responded with the first multilateral international agreement designed to protect refugees. The post of High Commissioner for Russian Refugees was created in 1921 and given to Dr. Fridtjof Nansen. The position became personally identified with Nansen, a charismatic Norwegian statesman and Polar explorer of continental renown. His efforts succeeded in culminating The Arrangement with regard to the Issue of Certificates of Identity to Russian Refugees, which was recognized by 54 states. ${ }^{71}$ As its name suggests, the agreement was largely concerned with providing identity papers and travel documents to stateless Russians, which became known as "Nansen Passports." Greeks and Turks fleeing the vicious Greek-Turkish war added to these refugee numbers and were issued

${ }^{66}$ HATHAWAY, supra note 61 , at 81 .

${ }^{67}$ See ARENDT at 275.

${ }^{68}$ Hathaway, supra note 49,350 . As with most mass population movements, the number of people who fled Russia is contested. Hathaway puts the number at 1.5 million.

${ }^{69} \mathrm{Id}$. at $350-51$.

${ }^{70} \mathrm{Id}$. at 351 . Arendt referred to the minorities and the stateless as "cousins-germane" who were left "rightless" after World War I. See HANNAH ARENDT, On the ORIGINS OF TOTALITARIANISM, 267-68. At that time, minorities and stateless alike were deprived of many of the benefits of citizenship. Many minorities were stateless, having had their citizenship revoked, and states refused to let many of them in. Many minorities and stateless could also be classified as refugees due to persecution. As discussed below, because of the overlap between these categories, the U.N. initially created a committee to draft international law on refugees and statelessness together. Eventually, two separate conventions were developed; the 1951 Convention Relating the Status of Refugees, the 1954 Convention Relating to the Status of Stateless Persons and the 1961 Convention on the Reduction of Statelessness. The latter focuses on preventing statelessness by requiring states to grant citizenship at birth, preventing them from withdrawing it, and preventing people from losing it in the event of territorial transfer. See 1961 Convention on the Reduction of Statelessness.

${ }^{71}$ Arrangement with regard to the Issue of Certificates of Identity to Russian Refugees, July 5, 1922, 355 L.N.T.S. 238. 
Nansen Passports as well. ${ }^{72}$ Nansen earned the 1922 Nobel Peace Prize for his efforts.

1. The Creation of Refugees as a Tool For State-Building

States viewed refugee flows as both a problem to be resolved and a solution to some of Europe's ailments. States used population transfer and exchange to create a better fit between nation and state. ${ }^{73}$ As nationalism rose, states viewed population transfers as a means of state-building, a solution to refugee crises, and a way to prevent future interethnic conflict. Even as such programs ostensibly aimed to protect minorities from violence, they often translated to brutal expulsions of people from their homes. Population transfers were particularly used in post-Ottoman states, where people and minorities had previously been transferred within the Empire. ${ }^{74}$ The benign-sounding term "population exchange" was first used to refer to a small-scale transfer between Bulgaria and Turkey in $1913 .^{75}$ Another transfer occurred between Greece and Bulgaria in 1919 when 50,000 people were moved from Bulgaria to Greece and about 100,000 did the opposite. ${ }^{76}$

The best-known mass expulsion is the Greek-Turkish Population Exchange. The 1923 Convention Concerning the Exchange of Greek and Turkish Populations ${ }^{77}$ was signed as part of the proceedings for the Treaty of Lausanne, which ended the Greek-Turkish War. ${ }^{78}$ It provided for "a compulsory exchange of Turkish nationals of the Greek Orthodox religion established in Turkish territory, and of Greek nationals of the Muslim religion established in Greek territory."79 The plan was controversial from

\footnotetext{
${ }^{72}$ Mazower, Mark. Dark Continent: Europe's Twentieth Century. New York: A.A. Knopf, 1999. Print. Page 61

73 Emma Haddad, The Refugee in InTERnational Society: BetweEn SOVEREIGNS (2008), at 120 .

74 ÖZsu, Umut. Formalizing Displacement: InTERnATIONAL LAW AND POPULATION TRANSFERS, at 52-55

${ }^{75}$ Bruce Clark, Twice a Stranger: The Mass Expulsions That Forged Modern GREECE AND TURKEY (2006) at 53.

76 Yossi Katz, Transfer of Population as a Solution to International Disputes: Population Exchanges between Greece and Turkey as a Model for Plans to solve the Jewish-Arab Dispute in Palestine During the 1930s. 11 POL. GEOGRAPHY 1, 57-22 (1992), at 5; see also MARK MAZOWER, DARK CONTINENT: Europe's TwENTIETH CENTURY, at 51.

${ }^{77}$ Convention Concerning the Exchange of Greek and Turkish Populations, Jan. 30, 1923, 32 L.N.T.S. 75.

${ }^{78}$ Harris Mylonas, The Politics of Nation-Building: Making Co-Nationals, REFUGEES, AND MINORITIES (2012), at 106.

${ }^{79}$ Convention Concerning the Exchange of Greek and Turkish Populations, Jan. 30,
} 
the outset. At Lausanne, no individual would take responsibility for the idea of the population transfer. Although the leaders of Turkey and Greece agreed that the populations could not live together, ${ }^{80}$ they argued over the human cost. Nansen, who eventually implemented the Exchange on behalf of the League of Nations, argued that he was following orders from the great powers-Britain, France, Italy, and Japan - to protect religious minorities. ${ }^{81}$ All of the drafters knew the exchange would cause massive human suffering, but believed it was in the long-term geopolitical interests of both states. ${ }^{82}$

The Exchange itself was better defined as a cruel forced expulsion. Nearly 2 million Greeks and Turks were ousted into each other's territory, most becoming refugees. ${ }^{83}$ Vast suffering was undeniable, even if some localities succeeded in integrating their populations. The international community effectively condoned the creation of mass refugee flows of Greeks and Turks, perversely, to protect these minorities from persecution. Such action was ostensibly justified in the name of national homogeneity and preventing another world war.

\section{Continued League of Nations Attempts to Regulate Refugees}

At the League's request and upon Nansen's own initiative, his office's mandate expanded quickly to encompass other groups of refugees. In 1924, after the mass expulsion of Armenians from Turkey, 38 League states signed a treaty to grant Armenian refugees similar legal protections to those of Russian refugees. ${ }^{84}$ Implementation problems quickly arose, due to considerable disagreement over definition of the terms "Russian refugees" and "Armenian refugees," which had been left vague. ${ }^{85}$ By 1926, the League extended Nansen's mandate to encompass seven additional

1923; See Egger at 371.

${ }^{80}$ Egger, at 71 .

${ }^{81}$ Clark, at 44

${ }^{82}$ Id.

${ }^{83}$ For a recent discussion of the population exchange, see HARRIS MYLONAS, THE POLITICS OF NATION-BUILDING: MAKING CO-NATIONALS, REFUGEES, AND MINORITIES (2013).

${ }^{84}$ Plan for the Issue of a Certificate of Identity to Armenian Refugees, May 31, 1924, 5 O.J.L.N. 969-970.

${ }^{85}$ An intergovernmental conference was held in 1926 to define the terms, resulting in the Arrangement relating to the Issue of Identity Certificates to Russian and Armenian Refugees, May 12, 1926, 48 L.N.T.S. 2004. This document required that Russian and Armenian refugees prove that they lacked the "protection" of their states of origin and had not acquired any other nationality. Only 28 states signed onto this new definition, and a successor treaty in 1928 left the terms again undefined. See Arrangement relating to the Legal Status of Russian and Armenian Refugees, June 30, 1928, 55 L.N.T.S. 2005. (Elsewhere cited as 89 LNTS No. 3663.) 
categories of refugees and stateless people in need of travel documents, primarily religious minorities. ${ }^{86}$ In 1928 , these protections were further expanded to include Kurds. Nansen proposed to extend his mandate still further, to more than 125,000 people left displaced, stateless, or unable to return to their homelands after WWI, including 16,000 Jews to whom Romania refused to grant citizenship. These proposals were rejected by the League as too expansive. ${ }^{87}$ During this time, the League also drew a distinction between stateless people, displaced people, and refugees. In doing so, the League signaled a willingness to protect only those who had fled their countries of origin, while tabling the problem of stateless and displaced people, especially Jews, to whom no country wished to grant citizenship.

Thus, in the interwar period, the protection of persecuted minorities and refugees, which were inextricable categories, increased in importance to the international community. The League's commitment to protecting dissidents from Russia and minorities from the former Ottoman Empire was strong. The League saw creating refugee flows and forced population displacement as part of a broader strategy to achieve homogeneity between nation and state, which was then viewed as the best way to protect human rights. But human suffering from the expulsions created a tremendous dark side to the lofty goals of peace and rights for a all.

\section{Responses to the Nazi Rise}

The refugee situation in Europe began to change dramatically as a result of the territorial advances and political persecution wrought by the Nazi regime. The National Socialist Party declared in the early 1930s that:

None but the members of the nation may be citizens of the State. None but those of German blood, whatever their creed, may be members of the nation. No Jew, therefore may be a member of the nation. ${ }^{88}$

Nazi policies quickly turned the ideals of the Minority Rights Treaties on their head. Germans comprised the largest minority group in Europe in the 1930s, a fact which is often forgotten ${ }^{89}$ Nazis began to use the existence of

\footnotetext{
${ }^{86}$ These included 150 Assyrians fleeing France, 19,000 Assyro-Chaldaeans fleeing the Middle East, and 150 Turkish dissidents living in Greece and the Middle East who were unable to return to their homeland. Hathaway, supra note 49, at 354-56.

${ }^{87} \mathrm{Id}$. at 354-55.

${ }^{88}$ Quoted in J. Simpson, Refugees: Preliminary Report of a Survey, 1938, at 59-65.

${ }^{89}$ Mazower, supra note 14.
} 
large German minorities in neighboring countries to justify territorial annexation to "protect" them. ${ }^{90}$ Besides systematic policies designed to harass and extinguish non-Aryans, the Nazis also enacted brutal policies against political opponents. Tens of thousands began to flee from Germany each year. ${ }^{91}$

\section{Early Refugee Protection Efforts During WWII}

Faced with increasing numbers of refugees, the League of Nations recognized the need for stronger refugee protections, but floundered when creating them. After Nansen's sudden death in 1930, the League did not immediately replace him. The League replaced the High Commissioner position with an International Office for Refugees, and convened an International Governmental Conference to draft the first International Refugee Convention in $1933 .^{92}$ The document, signed only by a few states, entrenched the deliberately imprecise 1926 and 1928 categories of refugee., and was largely restricted to providing refugees with travel and identity documents. ${ }^{93}$ Still, this early international refugee law was concerned with protecting particular ethnic and national groups, especially religious minorities, who were persecuted and fled their countries of origin and unable to return.

The Office of the High Commissioner quickly became consumed with protecting refugees from the Reich. In 1933, American James McDonald was appointed High Commissioner for Refugees coming from Germany (Jewish and Other). ${ }^{94}$ MacDonald resigned in 1935 in the face of widespread opposition by European states to his attempts to resettle Jewish refugees, stating that he was "virtually powerless" given the League's refusal to intervene in Germany to stop their flight. His successor, Sir Neill Malcom, arranged four narrow international agreements in response to Nazi territorial advances and persecution of minority groups. ${ }^{95}$

${ }^{90} I d$.

${ }^{91}$ Hathaway, supra note 49, at 362-63.

92 Convention relating to the International Status of Refugees, CLIX L.N.T.S. 3663 (1933)

${ }^{93}$ Hathaway, supra note 49, at 357.

94 Shauna Labman, Looking Back, Moving Forward: The History and Future of Refugee Protection, 10 CHI.-KenT J. INT'L \& COMP. L. 1 (2009).

${ }_{95}$ Plan for the Issue of a Certificate of Identity to Refugees from the Saar, XVI(2) L.N.T.S. 134 (1935); Provisional Arrangement concerning the Status of Refugees coming from Germany, XVII(2) L.N.T.S. 129 (1936); Convention Concerning the Status of Refugees Coming from Germany, CXCII L.N.T.S. 4461 (1938); Council Resolution on Refugees from the Sudetenland, 17 January 1939; Additional Protocol to the Provisional Arrangement and to the Convention concerning the Status of Refugees coming from Germany, XX(2) L.N.T.S. 73 (1939). 
Even as the Nazi terror worsened, states were unwilling to admit Jewish refugees. As such, they increasingly sought to keep the definition of protected persons under these agreements very narrow. Echoing earlier territorial definitions in the Russian and Armenian refugee agreements, some treaties were confined to refugees from newly captured Nazi territory, such as the Saar and the Sudetenland. State signatories were adamant that German refugees and stateless people had to be outside German territory and to prove that they could not receive the protection of the German government. ${ }^{96}$ Economic migrants were excluded, as were those moving for personal convenience. In May 1938, following the Anschluss, the League of Nations extended the High Commissioner's mandate to include minority groups and dissidents fleeing Austria. ${ }^{97}$ The High Commissioner succeeded in creating a new 1938 Convention Concerning the Status of Refugees Coming from Germany, to protect those with a bona fide fear of persecution. However, this document was ratified by only 8 states. ${ }^{98}$

\section{Refugee Protection Efforts Beyond Europe}

The plight of refugees - and the League of Nations' failure to protect them - began to attract attention outside Europe. By 1938, 150,000 German Jews, or 1 in 4, had fled the country. The Anschluss in 1938 brought another 185,000 Jews under German control. The U.S., which was not a member of the League of Nations, called its own conference at Evian in 1938 with the stated goal of coordinating support for Jews who had fled or wished to flee Germany. ${ }^{99}$ Franklin Roosevelt, under intense pressure to assist refugees, wished to use the conference to deflect domestic and international criticism. ${ }^{100}$

In terms of human rights, the Evian conference was a failure. 32 countries attended, along with a representative from the High Commissioner's office, non-governmental groups, and NGOs representing Jewish organizations from nearly every country in Europe. Roosevelt refused to send the Secretary of State or another high-level official to the conference, reflecting his ambivalence toward the issue. At the conference, the U.S. representative announced that it would make its quota of 19,000 German and Austrian refugees available to Jews, but claimed that it was not in position to take more Jews due to economic pressure and unemployment

${ }^{96}$ Hathaway, supra note 49 at 363-66.

${ }^{97} \mathrm{Id}$. at 366. 15,000 German-speaking refugees forced to leave the Sudetenland but who could not repatriate to Germany were also assisted by the High Commissioner.

${ }^{98}$ Labman, supra note 94, at 7.

${ }^{99}$ Evian Conference, Second Meeting (Public), (1938).

${ }^{100}$ See Richard BREITMAN, FDR AND THE JEWS (2013). 
as the country recovered from the Great Depression. Other countries gave similar excuses. Only the Dominican Republic agreed to take 100,000 Jewish refugees in exchange for substantial sums of money.

Emboldened by other countries' unwillingness to accept Jewish refugees at the conference, Germany launched the "Final Solution" to exterminate the Jews entirely. Perversely, the High Commissioner's office received the Nobel Peace Prize again in 1938 for its efforts to assist German refugees.

The one success of Evian was the creation of the Intergovernmental Committee on Refugees to aid Jewish resettlement from Germany. ${ }^{101}$ The Committee became the first international body to recognize that people still living in their countries of origin might qualify as refugees because they would be forced to immigrate. ${ }^{102}$ Its original mandate included racial, religious, and ethnic minorities and political dissidents still living in Germany and Austria as well as those who had already left but had not yet received permanent legal protections elsewhere. ${ }^{103}$ In 1943, the mandate was expanded to include people "who, as a result of events in Europe, have had to leave, or may have to leave, their countries of residence because of the danger to their lives or liberties on account of their race, religion, or political beliefs." It was updated again in 1946 to include people who were "unwilling or unable to return to their country of nationality or of former habitual residence." 104 This language foreshadowed the definition of refugee that would eventually be entrenched in the 1951 Convention.

Thus, the interwar years and World War II itself saw an increasing number of international agreements to protect refugees, but a large failure in refugee protection. Narrow international agreements to protect refugees developed on an ad hoc basis, in response to particular political events, and primarily on the basis of group protections. As the system of Minority Rights Treaties collapsed, concern with protecting religious and ethnic minorities and victims of political persecution remained at the core of each successive legal instrument. However, these instruments flatly failed to protect the Jews from genocide.

\section{E. Post-World War II Attempts at Protection}

After World War II, as word of Nazi atrocities spread to a horrified world, minority groups were found scattered across Europe. Jews and others

${ }^{101}$ See JACQUes Vernant, THe Refugee In THe Post-WAR World 26-27 (1953).

${ }^{102}$ Hathaway, supra note 49, at 371.

${ }^{103} \mathrm{Id}$. at 371 .

${ }^{104} I d$. at 371. This expansion allowed for refugees from the Sudetenland and Spanish Republicans to be included in the Committee's mandate. 
"liberated" from concentration camps were often forced to remain there, for lack of anywhere else to turn. Without access to whatever remained of their property and resources, many were forced to wear either their old concentration camp uniforms or SS garb taken from defeated soldiers. ${ }^{105}$ As one observer put it, it was unclear which of the two wardrobe choices they hated more. ${ }^{106}$ Hundreds of thousands fled to Palestine, remaining stateless until the founding of Israel in 1948. Millions more Jews and non-Jews were stranded amid the ruins of Europe, struggling to recoup their basic human dignity.

The League of Nations' failure to prevent the Second World War quickly discredited the organization and its related offices. The international community, recognizing the great need to provide legal protections to displaced people within Europe, created a new organization to succeed the High Commissioner's office. The United Nations Relief and Rehabilitation Administration (UNRRA) was established in 1943, even before the War ended, and before formal establishment of the U.N. itself. UNRRA had the narrow mandate of repatriating displaced people to their home countries, while refugees who were unable to return home, were referred to the Intergovernmental Committee. ${ }^{107}$ As the Cold War began, many Eastern Europeans refused to return home, and UNRRA refused to force them. Thousands, if not millions, remained trapped in camps. ${ }^{108}$

\section{The International Refugee Organization}

It was imperative for the fledgling United Nations to make displaced people an early priority. No organization with a mandate to preserve international peace and security and encourage respect for human rights could do otherwise and maintain legitimacy. ${ }^{109}$ As Harry Truman said in 1952, at stake was the "very outcome of the Cold War, in which the character, scope and sincerity of the free world's treatment of refugees and...overpopulation may be crucial factors." 110

Faced with unprecedented population displacement, the international community needed to redefine the term "refugee" for the new world order. In 1946, the U.N. General Assembly resolved to replace the prior refugee

${ }^{105}$ Lisa Malkki, From "Refugee Studies" to the National Order of Things, 24 ANN. REV. OF ANTHROPOLOGY 495, 499 (1995).

${ }^{106}$ Cite.

${ }^{107}$ Hathaway, supra note 49, at 372.

${ }^{108}$ CORINNE LEWIS, UNHCR AND INTERNATIONAL REFUGEE LAW: From TREATIES TO INNOVATION 8 (2012).

${ }^{109}$ U.N. Charter arts. 1, 76.

${ }^{110}$ Gerard Daniel Cohen, IN WAR's WAKE (2012) at _. 
agreements with a more comprehensive document. ${ }^{111}$ In the interim, among the U.N.'s early acts was to establish the International Refugee Organization as a temporary agency in April 1946. By 1947, the IRO had assumed the responsibilities of the Intergovernmental Committee and UNRRA, making its definition the only international legal definition of "refugee."112

The staff of the IRO also tackled its mission with the zeal that comes with the desire to serve a higher purpose. Paul Weis, among other IRO spokesmen, believed that their mission lay beyond protecting refugees and instead would "enforce a new standard of international conduct" linked to the emerging human rights regime. ${ }^{113}$ Indeed, the IRO's advocacy succeeded in including individual rights for refugees and stateless persons in the 1948 Universal Declaration of Human Rights and other international instruments. ${ }^{114}$ The IROs humanitarian relief work also influenced how refugee assistance would be perceived in the future. By 1945, the DP camps had evolved into "an alternative welfare state for the stateless." 115 UNRRA and IRO assistance evolved to include "food, clothes, housing . . . child welfare, healthcare, recreational and artistic activities, sport, education, language, and vocational training, as well as employment counseling." 116 Although many today would view this activity as humanitarian assistance, IRO staff viewed it as part of their human rights-based mission, important to restoring the dignity of the refugee before they could restore his citizenship.

With the creation of the IRO, the U.N. decided to handle the refugee problem holistically, and to define refugee in the most detailed terms yet. ${ }^{117}$ The IRO was charged with assisting any person:

who is outside of his country of nationality or former habitual residence, and who, as a result of events subsequent to the outbreak of the second world war, is unable or unwilling to avail himself of the protection of the Government of his country of nationality or former nationality. ${ }^{118}$

${ }^{111}$ G. A. Res. 8/1, U.N. Doc. A/RES/8/1 (Feb. 12, 1946).

${ }^{112}$ Hathaway, supra note 49, at 376.

${ }^{113}$ Paul Weis, "Future of Elan's Freedom: How IRO Will Enforce a New Standard of International Conduct," Wiener Library Bulletin 6 (September 1948), 6-8, cited in Cohen, supra note _, at 96.

${ }^{114}$ See Cohen, supra note _, at 96-99.

${ }^{115}$ Cohen, supra note _, at 66.

${ }^{116} \mathrm{Id}$.

${ }^{117}$ Paul Weiss, The International Protection of Refugees, AM. J. INT. LAW 193, 210-11 (1954); citing G.A. Res. 62/1, U.N. Doc A/RES/62/1 (Dec. 15, 1946).

${ }^{118}$ I.R.O. CONST., Annex 1. 
The IRO would assist four additional groups of people: 1) those considered refugees before World War II for reasons of race, religion, nationality or political opinion, 2) victims of the Nazis or their allies, 3) victims of the Spanish Falangists, and 4) Jews, foreigners, or stateless persons who had resided in Germany or Austria, were victims of Nazi persecution, and who had been detained in or returned to one of those countries and not yet resettled. Excepting those in groups 2 and 4, people would only become of concern to the organization if they could be repatriated or had "valid objections" to returning to their countries of nationality or former habitual residence. ${ }^{119}$ The chief ground for having a valid objection was persecution or fear of it, thus ensconcing the link between persecution and refugee status in international law. ${ }^{120}$

The IRO soon became known as "the largest travel agency" and "mass transportation system in the world." 121 After sorting out imposters, the IRO would assist "genuine" refugees and displaced persons "to return to their countries of nationality or former habitual residence, or to find new homes elsewhere."122 The Organization would also provide "legal and political protection" for refugees, terms that were left intentionally vague. ${ }^{123}$ The IRO established international agreements to secure travel documents and legal protections for refugees. ${ }^{124}$ The IRO eventually had an annual budget four times that of the United Nations, $40 \%$ of which was provided by the U.S. ${ }^{125}$ It resettled nearly 1 million refugees between 1947 and $1951 .{ }^{126}$

\section{Power Politics Intervene}

Power politics quickly affected the IRO's operations. While the entire international community agreed that minorities should be protected, the idea that political dissidents should be protected as refugees was sharply contested. At the behest of the Western bloc, the IRO went further than previous definitions of "refugee" by extending protection to political dissidents. Both the Soviet bloc and France strenuously objected to this

${ }^{119}$ Id., Annex 1, Section C.

${ }^{120} \mathrm{Id}$.

${ }^{121}$ Cohen, supra note _, at

122 I.R.O. CONST. PREAMBLE, $\mathbf{q} 3$.

${ }^{123}$ Weiss, supra note 117 , at 211.

${ }^{124}$ LEWIS, supra note 108, at 10.

${ }^{125}$ U.N. GAOR, 4th Sess., 265th plen. mtg., 912 (Dec. 1949).

${ }^{126}$ Labman, supra note 94 at 9. Of these, 239,000 were resettled in the U.S., 182,000 in Australia, 132,000 in Israel, 123,000 in Canada, and 170,000 in Europe. 
expansion of the term. ${ }^{127}$ The French delegate vehemently argued that political refugees should be the responsibility of those countries that chose to grant them asylum. ${ }^{128}$ When the Western bloc prevailed in including political dissidents, the Soviets refused to participate in the IRO from its outset.

The Soviets quickly moved to stall the IRO. The developing Cold War meant that the Eastern Bloc was unwilling to allow an organization largely funded by the West to operate freely. The IRO could only operate in those areas controlled by Western armies. In light of the developing Eastern Bloc, many refugees from the Soviet Union and Eastern Europe refused to return, and the West hardly encouraged them to do so. ${ }^{129}$ In contentious debates in the General Assembly and elsewhere, the Soviets accused the West of forcibly preventing displaced Easterners from returning home and using them for forced labor. ${ }^{130}$ While the U.S. argued for expansion of the term "refugee" on the basis that individuals had the right to seek "personal freedom" through migration, the Eastern bloc argued that it was wrong to "indirectly saddle democratic governments with liability for the maintenance of their emigrated enemies." "131 The Soviets called for forced repatriation rather than supporting those who chose to remain in camps. ${ }^{132}$ The Soviets also called out Western hypocrisy, noting that Africans fleeing wars of independence from their colonial masters represented "true" refugees, while the IRO remained focused on serving Western and European interests.

Western interests did, indeed, the scope of whom the Organization would protect. The IRO did not assist Palestinian, Korean, or South Asian refugees. The birth of the State of Israel in 1948 offered a partial solution to the refugee crisis in Europe while creating a new one in the Middle East. Hundreds of thousands of Palestinians became refugees in neighboring Arab states. Existing U.N. agencies had their mandates restricted to Europe, so the U.N. created another new agency to assist displaced Palestinians, the United Nations Relief and Works Agency, or UNRWA. ${ }^{133}$ The U.N.

${ }^{127}$ Id. at 378 .

${ }^{128} I d$. at 378 .

${ }^{129}$ See LEWIS, supra note 108, 12.

${ }^{130}$ See Kristen Walker, Defending the 1951 Convention Definition of Refugee, 17 GeO. IMMIGR. L.J. 583 (2002).

${ }^{131}$ U.N. GAOR, (30th Plen. Mtg.), at 423; 1(2) UNGAOR C.3 (27 ${ }^{\text {th }}$ Mtg.), p. 156, U.N. Doc. A/C.3/86, at 426 .

${ }^{132}$ Cohen, supra note _, at .

133 When the 1951 Convention was drafted, Arab governments also lobbied for Palestinians to be excluded, fearing that their inclusion would deflect international attention from solving the Palestinian problem. Irial Glynn, The Genesis and Development of Article 1 of the 1951 Refugee Convention, J. REFUG. STUD. 134, 140 (2011) ; AleX TAKKENBERG, 
expected UNRWA to be temporary, lasting only a few years until the Palestinian refugee problem was resolved. Its mandate and programs, and the refugee camps it administers, continue to this day. A similar organization was set up to assist Korean refugees by late 1950, the United Nations Korean Reconstruction Agency (UNKRA). Both organizations were primarily funded by the U.S. and thus largely under U.S. control.

Because they were protected by other U.N. agencies, Palestinians and Koreans were excluded from the definition of "refugee" that was eventually adopted in the 1951 Convention. The millions displaced by independence movements in South Asia in 1947 were left completely unprotected by international law. Loescher and Glynn have noted that Western interests shaped who received protection and who did not. Both the Palestinians and Koreans were given Agencies that "contributed to the U.S. goal of stabilizing areas deemed under threat of Communism," and the Palestinian agency supported U.S. goals in protecting its nascent Israeli ally. Meanwhile Indians and Pakistanis displaced in 1947 were not covered by another U.N. Agency or the 1951 Convention since they were outside the scope of U.S. and Western interests.

\section{F. Legalization of Human Rights and Refugee Rights}

While U.N. Agencies worked to protect refugees, the U.N. General Assembly was otherwise occupied with the Convention on the Prevention and Punishment of the Crime of Genocide. The Genocide Convention was adopted by the U.N. General Assembly on December 9, 1948, and entered into force on January 12, 1951. ${ }^{134}$ The Genocide Convention represented the culmination of years of tireless campaigning by lawyer Raphael Lemkin, who relentlessly visited states to ensure support for it outside of ordinary General Assembly channels. ${ }^{135}$ Jacob Robinson and Louis Henkin, who were concurrently involved in drafting the 1951 Convention, assisted

The STATUS OF PALESTINIAN REFUGEES IN INTERNATIONAL LAW (1998).

${ }^{134}$ Convention on the Prevention and Punishment of the Crime of Genocide, Dec. 9, 1948, 78 U.N.T.S. 277.

${ }^{135}$ Lemkin's battle is discussed at length in SAMANTHA POWER, A PROBLEM FROM HELL: AMERICA AND THE AGE OF GENOCIDE (2002). More recent work by historians has suggested that the Genocide Convention as a project relating to international criminalization of genocide than a project of international human rights law. However, this work suggests that Lemkin was primarily concerned with human rights projects such as the UDHR interfering with his efforts to establish the Genocide Convention. Moreover, others whom he recruited to his cause saw the Genocide Convention as a companion to other human rights efforts. See, e.g., Mira Siegelberg, Unofficial Men, Efficient Civil Servants, Raphael Lemkin In the History of International Law, 15 J. GENOCIDE RESEARCH 3, 297316 (2013). 
Lemkin in his efforts. The Genocide Convention prohibited systematic state actions "committed with the intent to destroy, in whole or in part, a national, ethnical, racial, or religious group." 136

Although scholarly debate exists as to whether the Genocide Convention was designed as a human rights instrument or an instrument of criminal law, it undoubtedly represented a critical step toward creating binding international law to protect minority rights. ${ }^{137}$ Naming and defining the crime made the term available and accessible to politicians, government officials, journalists, and activists who could use it to shame perpetrators, and eventually, to prosecute them. It was against the backdrop of Lemkin's work that the U.N. began to proscribe other categories of human rights violations, including the expulsion of persecuted people based on the very same group categories. It is no coincidence that international refugee law ranked high on the agenda of a fledgling U.N. determined to rectify the mistakes of the League of Nations and prevent another world war.

Up until this time, the U.N. had considered refugee issues to be temporary. Accordingly, its refugee assistance organizations had mandates designed to last only a few years. But by the early 1950s, 2-3 million refugees had already been assisted by international organizations, with no end in sight. ${ }^{138}$ Despite the continuing clarification of the refugee definition and consolidation of previous refugee regimes within the IRO, the organization was unable to solve the refugee problem as the international community had hoped. The IRO itself estimated that by the time its mandate expired in June 1950, 292,000 displaced persons in Europe would remain whom they had been mandated to protect.

Refugees became an issue of international concern, particularly in the U.S. By 1950, the New York Times was frequently running featured articles about the plight of the European displaced. ${ }^{139}$ The newspaper estimated that 10 million were displaced in Europe by 1950, due to the war and subsequent fighting and persecution. ${ }^{140}$ Meanwhile, millions more had

${ }^{136}$ Genocide Convention, supra note 134, Art. 2.

${ }^{137}$ See generally Siegelberg, supra note _.

${ }^{138}$ Weiss, supra note 117 , at 208.

139 See, e.g., Michael L. Hoffman, Central Europe's Refugees Still a Problem of the Age, N.Y. Times, Jul. 20, 1950; Michael L. Hoffman, Refugee Pressure Appears Renewed, N.Y. Times, Jul. 22, 1950; I.R.O. Offers to Aid Korean Fugitives, N.Y. Times, Aug. 5, 1950; After I.R.O.--what?, N.Y. TIMES , Jul. 26, 1950; Michael L. Hoffman, Central Europe's Refugees Still a Problem of the Age, N.Y. TIMES, Jul. 20, 1950; Vatican Aide Sees Long D.P. Problem, N.Y. Times, Mar. 22, 1950. C.L. Sulzberger, Refugee Epidemics Feared by Karachi, N.Y. TIMES, APR. 11, 1950; Care of Refugees Shifted, N.Y. TIMES, Apr. 30, 1950; Refugee Problem Far from Solved, N.Y. TIMES, Jul. 16, 1951.

${ }^{140}$ The New York Times estimated the number at 8 to 10 million as of 1950. U.N. Assembly to Get Draft on Refugee Aid, N.Y. TIMES, Aug. 01, 1950. 
been displaced outside of Europe, by the Korean War, the bloody birth of Pakistan and Bangladesh, and conflicts elsewhere..$^{141}$ In July 1950, The New York Times editorial page beseeched the world to act:

The dreadful fact remains that several million uprooted human beings still exist in Europe without homes and even, in all too many cases, without hope ... the refugee problem cannot simply be ignored. In political, economic, and above all, in human terms, it still demands the attention of the civilized world. ${ }^{142}$

The need for a permanent, binding instrument to protect refugees had become clear.

In 1949, ECOSOC authorized the creation of an Ad Hoc Committee on Statelessness and Related Problems with the primary task of drafting a convention to provide more permanent protection to refugees and displaced people. ${ }^{143}$ That same year, the U.N. Economic and Social Council (EcoSoc) also asked the Secretary General to plan for a new organization to assist refugees, and to define its new, broader mandate. ${ }^{144}$ Modern international refugee law was born.

\section{G. International Legalization: The 1951 Convention Relating to the Status of Refugees}

The 1951 Convention was drafted by refugees, for refugees. Before the Ad Hoc Committee on Statelessness met for the first time, three men in the legal office of the IRO prepared a template of the Convention. ${ }^{145}$ Foremost among them was IRO legal adviser Paul Weis. Weis made the protection of refugees and stateless people his life's work after experiencing their plight himself. Born in Austria, Weis was imprisoned in Dachau following the Anschluss. ${ }^{146}$ After several months, he was released, only to be detained as an enemy alien in Britain. Following his release to London, he joined the Grotius Society, an organization that incubated many of the international civil servants who later became the framers of post-World War II international law. ${ }^{147}$

${ }^{141}$ On Bangladesh, see Gary J. BASS, The Blood Telegram (2013).

${ }^{142}$ After I.R.O.--what?, supra note 139.

${ }^{143}$ E.S.C. Res. 248/B (XI) (Aug. 8, 1949); see also ZIMMERMANN ET AL., supra note 27 , at 308 .

${ }^{144}$ LEWIS, supra note 108 , at 12.

${ }^{145}$ Glynn, supra note 133, at 135 .

${ }^{146}$ Introduction, Weis Archive, Refugee Studies Centre, Oxford University, at 1.

${ }^{147} I d$. at 2. 
Weis worked for the World Jewish Congress during the war, and in 1947, became a legal adviser to the International Refugee Organization. He received his doctorate in international law from the London School of Economics in 1954. He later joined UNHCR as a legal adviser, a position he retained until his retirement in 1967, after which he continued to advise the organization until his death. ${ }^{148} \mathrm{He}$ was the chief architect of the 1961 Convention on Statelessness and Related Problems, and he authored seminal documents on the protection of refugees and stateless people well until his later years. ${ }^{149}$ Weis's writings, and his commentary on the travaux preparatoires of the 1951 Convention, form much of what we know about the framing of international refugee law.

Besides Weis, many other delegates to the Ad Hoc Committee had long careers devoted to human rights, and knew each other from their prior work. The other two drafters from the IRO office were Gustave Kullman and Jacques Rubenstein. Kullman, a Swiss legal expert, served as Deputy High Commissioner for Refugees in the League of Nations during World War II. ${ }^{150}$ After Rubenstein escaped the Bolshevik Revolution, he assisted in penning the 1928 Arrangement on Russian Refugees and the 1933 Refugee Convention, and lobbying internationally for both of them. ${ }^{151}$ The UK Representative, Samuel Hoare, had been Deputy High Commissioner under Nansen. ${ }^{152}$ Jacob Robinson, the Israeli Representative and his brother Nehemiah Robinson, the Representative from the World Jewish Congress, had been Weis's mentors at the WJC. ${ }^{153}$ Jacob Robinson served as Senior Legal Adviser to the prosecution team at Nuremberg, under U.S. Chief Counsel (and later Supreme Court Justice) Robert Jackson. ${ }^{154}$ Later, he worked for the U.N. on the drafting of the Human Rights Commission's Legal Framework and Genocide Convention. ${ }^{155}$ Louis Henkin served as the U.S. delegate from his post in the State Department's U.N. Division. Henkin and Robinson, too, had been working on draft Conventions for more than two years before the time of the first meeting of the Ad Hoc Committee.

Concerns for protecting human rights motivated the drafters of the 1951 Convention in both the IRO and the Ad Hoc Committee on

${ }^{148}$ Introduction, Weis Archive, supra note 146, at 2.

149 See, e.g., Paul Weis, Development of Refugee Law, 3 Mich. YBI LEG. STUD. 27 (1982).

${ }^{150}$ Glynn, supra note 133 , at 135-6.

${ }^{151}$ Id. at 135 .

${ }^{152}$ Id. at $7-8$.

${ }^{153}$ Gilad Ben-Nun, The Israeli Roots of Article 3 and Article 6 of the 1951 Refugee Convention, 27 J. Refug. STUD. 101-125 (2014), at 7.

${ }^{154} \mathrm{Id}$. at 5.

${ }^{155} I d$. at 6. 
Statelessness and Related Problems. In Weis's words, the goal of the drafters was to "place refugees on equal footing with the citizens of the countries of refuge, in conformity with the principle of non-discrimination set forth in the Universal Declaration of Human Rights." 156 To this end, the drafters included a specific reference to Article 14 of the UDHR, the right to seek and enjoy asylum in other countries, in the Convention's preamble. Weis acknowledged, however, that this was an unattainable goal in many ways. He noted that even in countries with "very liberal reception policies," it was clearly not possible to give refugees the same treatment as nationals, and no country would truly act in this way. ${ }^{157}$

The human rights lawyers were faced with a challenge. Their goal was to create a draft that would appeal to as many states as possible and that would include all categories that might eventually fall under the High Commissioner's mandate. The IRO draft convention included a right to asylum, as did the Universal Declaration of Human Rights, in addition to refugee protections. Despite its creation of a potentially far-reaching international legal right, Kullman believed that the draft was "'realistic' in the sense that it aims at not going beyond what can reasonably be demanded of a liberal democratic state." 158

\section{Politics and Human Rights Collide}

Despite the best intentions of these men, politics quickly began to overshadow concerns with human rights. Against the backdrop of rising Cold War tensions, dialogue over the Convention soon devolved into the rhetoric of the Eastern and Western blocs. The initial Ad Hoc Committee comprised delegations from thirteen states: Belgium, Brazil, Canada, China (Taiwan), Denmark, Israel, Poland, Turkey, Soviet Union, the United Kingdom, United States and Venezuela. NGOs and representatives of specialized U.N. Agencies, including UNHCR, also participated in the drafting process.

The U.S. and Russia clashed over the issue of whether stateless people should be included in the Convention. The Ad Hoc committee largely agreed that the rights of refugees and stateless people should be severed into two different international legal documents. While the United Kingdom and Belgium supported an inclusive document, the United States strenuously argued that the rights of refugees were more urgent and

156 Paul Weis, The Refugee Convention-Travaux Préparatoires analysed WITH A COMMENTARY (2004), at 15.

${ }^{157} \mathrm{Id}$. at 15.

${ }^{158}$ Glynn, supra note 133, at 136. 
pressing than the rights of stateless people. ${ }^{159}$ The U.S., through Henkin, argued that refugees presented a bigger, more urgent, and distinct problem of humanitarian needs. ${ }^{160}$

The Soviet Union, which wished to quell protests from those whose citizenship it had revoked following the Bolshevik revolution, balked at this characterization. The Soviets, by contrast, were against protecting refugees, fearing that the Convention would be used against them politically by the Western bloc. Soviets characterized refugees as "traitors who are refusing to return home to serve their country together with their fellow citizens."161 After France supported the U.S. position, the matter of statelessness was tabled pending discussion of a second convention. ${ }^{162}$ In protest, the Soviet and Polish delegations eventually resigned from the Ad Hoc committee and refused to participate in the drafting or sign the Convention. ${ }^{163}$ The official reason for their withdrawal was that they did not consider Taiwan to be a legitimate U.N. member, but it is widely recognized that the Soviets likely opposed the creation of a new international convention to protect refugees, much as they were opposed to the IRO before it. ${ }^{164}$ Although the committee concluded its work on February 15, 1950, Robinson doubted that the Convention would ever be accepted by states. ${ }^{165}$

\section{Defining Refugees}

The delegates to the Ad Hoc Committee viewed broad international commitment as critical to solving refugee issues ${ }^{166}$ To assure the broadest possible support for the Convention, EcoSoc called for a Conference of

\footnotetext{
${ }^{159}$ U.N. ESCOR Ad Hoc Committee on Statelessness and Related Problems, U.N. Doc E/AC.32/L.T (1950).

${ }^{160}$ See Statement of Mr. Henkin of the U.S., U.N. ESCOR Ad Hoc Committee on Statelessness and Related Problems, Summary Record of Second Meeting, at 6, U.N. Doc. E/AC.32/SR.2 (1950).

${ }^{161}$ Statement of Mr. Soldatov of the U.S.S.R., in 5 U.N. GAOR $\left(325^{\text {th }}\right.$ plen. Mtg.) at 670, U.N. Doc. A/1682 (1950). See James Hathaway, Reconsideration of the Underlying Premise of Refugee Law, 31 HARV. INT'L L. J. 129, 129 (1990). For background on the development of a Cold War rift on international refugee law, see Georg Schwarzenberger, The Impact of the East-West Rift on International Law, 36 TRANSACTIONS OF THE GROTIUS SOCIETY 243 (1950).

${ }^{162}$ The Convention Relating to the Status of Stateless Persons, 360 U.N.T.S. 117, was eventually passed on September 28, 1954 and entered into force on June 6, 1960.

${ }^{163}$ Kristen Walker, Defending the 1951 Convention Definition of Refugee, 17 Geo. IMMIGR. L.J. 583 (2002), at 591.

${ }_{164}$ ZIMMERMANN ET AL., supra note 27, at 54.

${ }^{165}$ Bin-Nun, supra note XX.

${ }^{166}$ LEWIS, supra note 108, at 18; Walker, supra note 130, at 594-95 (citing statement of President of the Ad Hoc Committee).
} 
Plenipotentiaries to further debate the terms of the Convention and ratify it. Since 1922, each successive international legal instrument developed for refugee protection had fewer states parties than the preceding one. ${ }^{167}$ The U.N. did not want to create an overbroad Convention that states would be unlikely to sign. ${ }^{168}$ Western countries, led by the U.S., wanted the definition of refugee to be broad enough to cover any dissidents leaving the Eastern bloc. ${ }^{169}$ However, they wanted the definition to be precise enough that Soviets could not use it to their political advantage, and so left socioeconomic rights outside of the definition. ${ }^{170}$ In the end, key terms within the definition were left intentionally vague to allow signatory states wiggle room in their domestic interpretation of the Convention. ${ }^{171}$ Much dialogue during the drafting process focused on how to determine who was a "bona fide" refugee, but all determination procedures were ultimately left out of the text of the Convention itself. ${ }^{172}$

The definition of "refugee" within the Convention was hotly contested, and took the bulk of the drafters' time. According to Weis, deliberation on the definition of the term "refugee" reflected governments' desire to clearly define internationally protected refugees versus other people who were not in need of, or not deserving of, international protection. ${ }^{173}$ Surprisingly, there was little debate over the core of the definition: the protection of people persecuted on the basis of race, religion, nationality, or political opinion. ${ }^{174}$ This definition of refugee was, by this point, already well-defined in previous international legal instruments and the IRO Convention. The international community's concern with protecting the rights of minorities, included in the Universal Declaration of Human Rights, further bolstered the ideal of protection of minority rights entrenched by the 1951 Convention. The Convention itself referenced the UDHR as a source.

States' concerns with balancing their commitments to human rights with national security concerns dominated discussion at the conference. Delegates, citing state commitments and the values embodied in the Universal Declaration, expressed human rights aims. France and the UK, in particular, expressed lofty goals of broadly defining "refugee" early in the

${ }^{167}$ LEWIS, supra note 108 , at 17.

${ }^{168}$ Walker, supra note 130, at 593.

${ }^{169}$ Id. at 591; see also ZIMMERMANN ET AL., supra note 27, at 472.

${ }^{170}$ James C. Hathaway, A Reconsideration of the Underlying Premise of Refugee Law, 31 HARV. INT'L. L.J. 129 (1990), at XX.

${ }^{171}$ ZIMMERMANN ET AL., supra note 27, at 50.

${ }^{172}$ Id., 50-51.

${ }^{173}$ Weiss, supra note 117 , at 199.

${ }^{174}$ Weis, supra note 149, at XX. 
debates. ${ }^{175}$ While acknowledging its own concern with masses of refugees, France initially proposed broad language that would extend refugee protection to anyone seeking asylum, for whatever reason, and anyone fearing persecution, whether inside or outside his country of nationality. ${ }^{176}$

However, France and Britain were tempered by realist concerns of being overwhelmed by large numbers of refugees. Most states, led by the UK, were concerned with overcommitting themselves to unforeseen numbers of refugees, and thus preferred to narrow the definition of "refugee" from those protected by previous instruments. France and the UK were especially concerned about being overrun by refugee claims from their colonial interests, many of whom were contemporaneously engaged in struggles for self-determination. ${ }^{177}$ The UK was generally known for objecting within the U.N. to construe human rights treaties narrowly, fearing that their current and former colonial subjects would use such treaties against them. ${ }^{178}$ Accordingly, throughout the drafting process, the UK remained committed to human rights as an ideal while in practice attempting to narrow its obligations as much as possible. ${ }^{179}$

Other countries followed the UK in expressing concerns about floods of refugees overwhelming their borders. Sweden and Turkey, expressed concerns that the Convention might create a "pull factor" for refugees, and that security concerns and infrastructural limitations might limit their ability to manage these new refugees. Sweden noted that it would like to continue its liberal policies toward refugees, "but the fact must be taken into account that its capacity for absorbing large numbers was limited and that . . considerations of national security must play a certain part." 180 The Italian, Turkish, and Lebanese delegates echoed these concerns. ${ }^{181}$ Like France and the UK, the United States seemed torn between its own commitment to human rights ideals, its desire to manipulate human rights as an element of its Cold War foreign policy strategy, and its own skepticism of international law. Weis summarized the debates: ${ }^{182}$

The United States does not want to include unknown groups in the definitions, fearing that this may result ultimately in financial

175 Glynn, supra note 133, at 137 (citing Weis correspondence which states that the UK initially wanted a definition that "included all unprotected persons.").

${ }^{176}$ ZIMMERMANN ET AL., supra note 27, at 309.

${ }^{177}$ Walker, supra note 130, at 592; ZIMMERMANN ET AL., supra note 27, at 61.

${ }^{178} \mathrm{Id}$

${ }^{179}$ On UK and U.S. foreign policy vis-à-vis human rights, see Mazower, supra note 14 , at 393-4.

${ }^{180}$ Quoted in Walker, supra note 130, at 593.

${ }^{181}$ Id. at 593-94.

${ }^{182}$ Quoted in Glynn, supra note 133, at 137. 
commitments. France and Great Britain were in favour of a broad definition of refugees - the United States in favour of enumeration. The latter point of view prevailed.

France eventually withdrew its liberal proposal, agreeing that many states would be unwilling to sign onto such a broad definition. The definition that was eventually adopted closely resembled the U.S. proposals.

The Conference agreed on narrowing the definition to stress that refugees' reasons for fearing persecution needed to be directly connected to their flight abroad. ${ }^{183}$ The "well-founded fear of persecution requirement" in the 1951 Convention definition replaced the approach of prior refugee protection agreements, which delineated places of origin or categories of people to be protected. ${ }^{184}$ The term "persecution" was left deliberately undefined, with France wanting to link it to violations of human rights found in the UDHR, and the U.S. wanting to leave it vague so that it could reserve its small resettlement capacity for dissidents from the Soviet bloc.

This agreed-upon definition, then, which stands today, says that a refugee is someone who:

. . owing to wellfounded [sic] fear of being persecuted for reasons of race, religion, nationality, membership of a particular social group or political opinion, is outside the country of his nationality and is unable or, owing to such fear, is unwilling to avail himself of the protection of that country; or who, not having a nationality and being outside the country of his former habitual residence as a result of such events, is unable or, owing to such fear, is unwilling to return to it. ${ }^{185}$

The Plenipotentiaries also agreed that reservations to Article 1 would be impermissible because they would conflict with the object and purpose of the treaty. ${ }^{186}$

${ }^{183}$ ZIMMERMANN ET AL., supra note 27, at 323.

184 ZIMMERMANN ET AL., supra note 27, at 335.

${ }^{185}$ The 1951 Convention Relating to the Status of Refugees, U.N. General Assembly, Resolution 2198 (XXI) (July 28, 1951) (hereinafter, “1951 Convention”).

186 Declarations, however, were acceptable and were made by four states. The Netherlands, Turkey, Ecuador, Mexico all clarified that their signing of the 1951 Convention did not imply their acceptance of prior international agreements involving refugees, to which they were not parties. The Netherlands also refused to regard Ambionese transported by the Netherlands after Indonesian independence as refugees. In the boldest declaration, Mexico clarified that its Government would determine refugee status without prejudice to the Convention definition. See ZimmERMANN ET AL., supra note 27 , at $312-313$. 


\section{Conflict over Temporal and Geographic Limitations}

The primary source of controversy over Article 1 of the Convention was whether the Convention would be universally applicable or include temporal and geographic restrictions. Most countries did not wish to sign onto a Convention that would commit them to the protection of indeterminate numbers of refugees claiming a lack of national protection in the wake of World War II. ${ }^{187}$ Ultimately, to ensure the broadest possible acceptance of the Convention, the Conference of Plenipotentiaries adopted a restriction limiting the Convention to events occurring before $1951 .^{188}$

The inclusion of a geographic restriction was even more controversial. The U.S. and European states wanted to limit the Convention to events happening within Europe. Many countries did not wish to open themselves to refugee claims emanating from the developing world. As Henkin deftly explained, certain refugee groups in the world were simply too large for the U.S. to grant protection to them. Citing the 600,000 Palestinians already under U.N. protection, 6 million ethnic Germans who had returned to Germany from elsewhere in Europe, and new Kashmiri and Indian refugees, he described a universal definition as an infeasible "blank cheque" that would "undertake obligations toward future refugees, the origin and number of which would be unknown." 189 The French delegation strenuously argued that all refugee problems were regional, and that adopting a universal definition to solve all refugee problems would be "futile." 190 These states also noted that previous refugee agreements had been limited in their geographical scope.$^{191}$ Developing states, particularly Mexico, Pakistan, and India, vigorously protested any geographic restriction, arguing that such a limitation would undermine the universality of the Convention and its human rights aims. ${ }^{192}$ Eventually, the Holy See brokered a compromise, allowing individual states the choice to limit the scope of the Convention to events occurring in Europe, while underscoring the universal aims of the Convention elsewhere in the text. The Convention itself, in Article I.B., required states to make a declaration at the time of signature, ratification, or accession, stating whether they intended the Convention to be geographically limited to events occurring in Europe

\footnotetext{
${ }^{187} I d$. at $350-51$.

${ }^{188}$ Id. at 322; 1951 Convention, supra note 2, Article I, A.(2).

${ }^{189}$ Henkin, cited in Glynn, supra note 133, at 138.

${ }^{190}$ ZIMMERMANN ET AL., supra note 27, at 471.

${ }^{191} I d$. at 470 .

${ }^{192} I d$. at $469-71$.
} 
alone. ${ }^{193}$

Once "refugee" was defined, states' concerns with protecting their national security remained a prominent theme throughout the rest of the conference. According to the travaux, the most hotly contested provision was Article 9 of the Convention, which permitted a state to take provisional measures with respect to a particular person on national security grounds "in time of war or other grave and exceptional circumstances," pending determination that the person is a "bona fide refugee." At the core of the Convention is the jus cogens norm of non-refoulement, the concept that no signatory state will return a refugee to his country of origin if "his life or freedom would be threatened on account of his race, religion, nationality, membership of a particular social group, or political opinion."194 While most states did not contest the inclusion of this norm, nor the statement of its non-derogable nature, Weis noted the difficulty of deducing a duty of states "to refrain from actions which may lead to the return of a refugee to a country where he may become the victim of persecution" without conflicting with the doctrine of a state's unlimited right to regulate the admission of aliens." "195 Eventually, the definition of "bona fide" refugee was not included in the text of the Convention and was left intentionally vague.

\section{H. Human Rights versus Security Interests}

Thus, with the signing of the 1951 Convention and the creation of UNHCR, states crafted a delicate compromise between human rights and their sovereign right to restrict entry to their borders. On one hand, the international community moved solidly toward treating refugee rights as human rights guaranteed to individuals rather than legal protections for particular groups. Although states could opt into a geographical restriction, the Convention was also the first refugee agreement that was explicitly designed to be universal in application to all refugees, regardless of their country of origin. The concern of the drafters with protecting the rights of racial, religious, and national minorities was clear. However, security concerns limited the definition of refugee, and most discussion centered on ensuring that the Convention was not unduly onerous on states. Much of the Convention was left intentionally vague, requiring interpretation by

1931951 Convention; discussed in Paul Weis, The 1967 Protocol Relating to the Status of Refugees and Some Questions of the Law of Treaties, 42 BRIT. YB INT'L. L. 39 (1967).. States could also limit the scope of the Convention ratione personae, per the terms of this article of the Convention.

${ }_{195}^{194}$ See 1951 Convention, supra note 185.

${ }^{195}$ Weiss, supra note 117, at 199. 
domestic courts with respect to even some very basic issues of who counted as a refugee. ${ }^{196}$

While other commentators have argued that the inclusion of the term "political persecution" was merely a relic of Cold War politics, the historical record does not support this claim. ${ }^{197}$ The use of the category of persecution on the basis of political opinion was later used expressively as a foreign policy tool against the Soviet Union, as discussed above. However, the category of political persecution was already established in previous refugee instruments that the 1951 Convention succeeded. ${ }^{198}$ Zimmerman notes that, despite the lack of participation by Eastern bloc countries in the drafting, it is unlikely that the definition of refugee would have looked any different absent the Cold War context. ${ }^{199}$ The Cold War merely affected only the scope of the limitations, which were deliberately formulated so as not to exclude refugees from communist Europe as long as communist regimes were in power. ${ }^{200}$

While the Convention was an achievement for human rights, it was a victory for state interests as well. Many refugee advocates perceived state interests to have prevailed. Weis and his colleagues were "horrified" by the results. ${ }^{201}$ In correspondence to Kullman, Weis said, "The less clear, however, the definitions are, the more scope there will be for divergences of interpretation . . . I have a dim vision of the chaos that will ensue." 202 Kullman replied that the temporal restriction "was not merely unjust but also impractical." 203 Rubenstein noted that governments were stubbornly stuck to the view that history began in 1939 and ended in 1944, and thus were blinded to refugees occurring in any other circumstances. ${ }^{204}$ While many delegates entered the conference of Plenipotentiaries with the highest of hopes, they were dashed by power politics and stringent state security measures enacted in a world still reeling from the scars of war.

\section{The Creation of UNHCR}

${ }^{196}$ ZIMMERMANN ET AL., supra note 27, at 50.

197 See Michael S. Teitelbaum, Immigration, Refugees, and Foreign Policy, 38 InT. ORGAN. 429-450 (1984), at 431.

${ }^{198}$ Weis, supra note 193 , at 39.

199 ZIMMERMANN ET AL., supra note 27, at 59, 67; but see Hathaway, supra note 49, (stating that the "political opinion" category of the 1951 Convention was directly influenced by Cold War politics at the time)

${ }^{200}$ ZIMMERMANN ET AL., supra note 27, at 56.

${ }^{201}$ Glynn, supra note 133, at 137.

${ }^{202}$ Weis, quoted in $i d$, at 138.

${ }^{203} \mathrm{Id}$.

${ }^{204}$ Id. 
The U.N. designed a unique administrative agency to supervise the 1951 Convention even before it was signed. ${ }^{205}$ In December 1950, the U.N. General Assembly passed a statute creating the Office of the United Nations High Commissioner for Refugees (UNHCR) with an initial mandate of three years. ${ }^{206}$ UNHCR's Statute defined a refugee as anyone who previously enjoyed the protection of the IRO, along with those meeting a definition of "refugee" nearly identical to that in the 1951 Convention, but containing no geographic or temporal restriction.

Effectively, the agency's operations were based on the legal principle of complementarity: the international organization would step in to grant a remedy where sovereign states had failed. ${ }^{207}$ UNHCR's Statute defined its work as primarily legal. The agency's goal was to provide international protection to refugees, a vague term that was understood to mean legal protections that states were unable to provide. ${ }^{208}$ As the U.N. saw it, UNHCR had four primary responsibilities related to international refugee law: "[p]romoting the conclusion and ratification of international conventions for the protection of refugees, supervising their application and proposing amendments thereto." 209 For the U.N.'s purposes, UNHCR's job was to work with governments to establish legal arrangements for refugees through international conventions and otherwise. ${ }^{210}$ According to its statute, UNHCR was not to serve as a humanitarian organization in its own right, but could facilitate and coordinate private organizations wishing to assist refugees. ${ }^{211}$ Thus, researchers have observed that UNHCR was initially designed "to do very little and do only what states told it to do." 12 European states and the U.S. still viewed its existence as temporary, and in any case, within their control.

\section{J. The Expansion of International Refugee Law: The 1967 Protocol}

205 On administrative functions of UNHCR, see Goldenziel, supra note 24.

${ }^{206}$ Cite UNHCR Statute.

207 See Itamar Mann, Flagless Vessel: Human Rights as a Law of Encounter, TEXAS J. INT'L L. _ (forthcoming). Compare complementarity in international criminal law, in which an international court steps in only when state courts do not have the capacity to fulfill their legal obligations to society. U.N. General Assembly, Rome Statute of the International Criminal Court (last amended 2010), 17 July 1998.

${ }^{208}$ Weiss, supra note 117 , at 211.

209 Statute of the Office of the United Nations High Commissioner for Refugees, U.N.G.A. Res. 428 (V), Dec. 14, 1950, paragraph 8a (UNHCR Statute).

${ }^{210}$ Weiss, supra note 117 , at 211.

${ }^{211}$ UNHCR Statute, supra note 209, para 8.

212 Michael BARNETT \& MARTHA FinNEMORE, RUlES FOR THE WORLD: INTERNATIONAL ORGANIZATIONS IN GLOBAL POLITICS (2004), at 73. 
Over time, discrepancies between the 1951 Convention and the realities faced by states throughout the world became increasingly problematic. Like most international law, the concept of international refugee law developed in Europe. Its application then became problematized as it spread elsewhere. First, the Convention's temporal limitation, and its acceptance by some states and not others, created a disjuncture in the legal status between those who became refugees before and after 1951. Particular problems arose upon the Hungarian refugee crisis of 1956 and the Soviet occupation of Czechoslovakia in 1968. Thanks to the legal genius of Paul Weis, UNHCR interpreted these as after-effects of earlier events, and those displaced were given refugee status. ${ }^{213}$ However, other discrepancies in treatment remained based on the temporal restriction.

Second, the Convention's geographic limitation, and its acceptance by some states and not others, caused problems of interpretation. Hundreds of thousands of refugees fled from Africa and Asia during the 1950s and 1960 s, as colonization gave way to fierce fights over self-determination. ${ }^{214}$ As these states began to approach the U.N. and UNHCR for assistance, it became clear that such a geographic restriction was no longer tenable. Moreover, the Organization for African Unity had, by this time, adopted a broader definition of the term "refugee" in its own regional Convention, and was pressuring UNHCR to adopt that definition. ${ }^{215}$ Because of the geographic restriction, UNHCR was becoming increasingly criticized for providing "irregular" assistance to groups of refugees - and indeed, whether it considered groups of displaced people to be refugees at all - based on their countries of origin and relationship to Cold War politics. ${ }^{216}$

Third, an increasing discrepancy arose between the legal definition of refugee and the broader scope of UNHCR's mandate as defined in its statute. $^{217}$ In the face of growing numbers of refugees in Africa and elsewhere, UNHCR grew increasingly frustrated with its limited support

${ }^{213}$ LEWIS, supra note 108.

${ }^{214}$ Weis, supra note 193.

215 The Organization for African Unity's 1969 Convention Governing the Specific Aspects of Refugee Problems in Africa defines a refugee as, “. . . every person who, owing to external aggression, occupation, foreign domination or events seriously disturbing public order in either part or the whole of his country of origin or nationality, is compelled to leave his place of habitual residence in order to seek refuge in another place outside his country of origin or nationality." Organization for African Unity (OAU), Convention Governing the Specific Aspects of Refugee Problems in Africa, Sept. 10, 1969, 1001 U.N.T.S. 45. See also Statement of Mr. Waldron-Ramsey, delegate of the United Republic of Tanzania, at the Economic and Social Council's $1453^{\text {rd }}$ Meeting, 18 November 1966.

${ }^{216}$ LEWIS, supra note 108 , at 27-28.

${ }^{217}$ Weis, supra note 193, at 40, says this discrepancy is actually between the personal scope of the Convention and the "competence ratione personae" of UNHCR defined in its statute. 
from the international community, as accessions to the Convention were lower than expected. ${ }^{218}$ As Cold War rhetoric continued to dominate discussion of refugees in the U.N., the Soviet Union repeatedly pointed out that the Convention was never adopted by the U.N. itself, but by an unrepresentative Conference of Plenipotentiaries comprising only 26 states that were primarily from Western Europe. ${ }^{219}$ UNHCR sought to revise or create new international refugee law to make it more widely and universally applicable..$^{220}$

Non-Western states pushed successfully to change the 1951 Convention to reflect their needs. ${ }^{221}$ In 1965, the Carnegie Endowment of International Peace, with support from the Swiss government and in consultation with UNHCR, held a "Colloquium on Legal Aspects of Refugee Problems with particular reference to the 1951 Convention and the Statute of the Office of the United Nations High Commissioner for Refugees" in Bellagio, Italy. ${ }^{222}$ Thirteen legal experts from across the world participated in their personal capacities, including Louis Henkin, who was still working for the U.S. State Department. The experts agreed that, for humanitarian reasons, it was now imperative for refugees not currently covered by the Convention to be given similar benefits by way of a binding international instrument. ${ }^{223}$ The urgency of the situation meant that there was no time to prepare and adopt a new Convention or revise the existing one. ${ }^{224}$ Instead, they proposed a Protocol to the Convention to remove the temporal and geographic restrictions in the 1951 Convention. So as not deter state parties to the Convention from accepting the Protocol, they permitted existing declarations limiting the application of the Convention to continue unless states explicitly withdrew them. ${ }^{225}$ The High Commissioner polled the states parties to the Convention and found them to be overwhelmingly enthusiastic about the removal of the dateline. ${ }^{226}$

218 Sara Davies, Redundant or Essential? How Politics Shaped the Outcome of the 1967 Protocol, InT. J. ReFug. LAw (2008). at 703. Only 50 states by that time were parties to the Convention. See statement of High Commissioner Prince Sadruddin Aga Khan, Economic and Social Council, $1453^{\text {rd }}$ Meeting, 18 November 1966.

${ }^{219}$ Weis, supra note 193, at 46-47.

${ }^{220}$ Davies, supra note 218 , at 705-6.

${ }^{221}$ Several states first raised the need for an amendment to the Convention in the 1964 and 1965 meetings of ExCom, the Executive Committee of the High Commissioner's Program. Weis, supra note 193, at 41.

${ }^{222}$ Id. at 41 .

${ }^{223}$ Id. at $42-43$.

${ }^{224} \mathrm{Id}$. at 43 .

${ }^{225} \mathrm{Id}$. at 43 .

${ }^{226}$ Statement of High Commissioner Aga Khan, Economic and Social Council, 1453rd Meeting, 18 November 1966, Annual report of the United Nations High Commissioner for 
Recognizing the urgency of the situation ExCom, through EcoSoc, submitted the draft Protocol to the General Assembly so that the Secretary General could open the Protocol for government accession as quickly as possible. $^{227}$

On many levels, the Protocol was a tremendous success. It expanded Convention protections to refugees throughout the world. Since 1967, the numbers of states parties to the Convention or Protocol grew from 50 to $147 .^{228}$ The U.S., which initially refused to sign the 1951 Convention, acceded to the Protocol in 1968. However, Gil Loescher has noted that Western states were motivated to sign the 1967 Protocol to restrict refugee protections, not to increase them. The existence of the Organization of African Unity's expansive definition encouraged Western countries to sign on to the lesser of two known evils. ${ }^{229}$

\section{K. Post-1967: Legal Contraction, Aid Expansion}

Nominally, the 1951 Convention has succeeded in harmonizing refugee law. Many states, including the U.S., have revised their refugee and asylum policies to bring them into line with international refugee law, although neither the Convention nor the Protocol require this. The U.S., for example, enacted the Refugee Act of 1980 in large part to match the standards of international refugee law.

However, the 1951 Convention and 1967 Protocol are widely regarded as increasingly irrelevant because of their inapplicability to modern displacement crises. ${ }^{230}$ Scholarly criticisms focus on the fact that the 1951 Convention does not provide a legal basis for protecting most of the world's displaced people, including those displaced by civil conflict, famine, and natural disaster. Most strikingly, the 1951 Convention offers no

Refugees on measures to extend the personal scope of the Convention of 28 July 1951

relating to the status of refugees, available at http://legal.un.org/avl/ha/prsr/prsr.html\#

${ }^{227}$ Id. This procedure was followed because it was necessary to submit through committee since the recommendation came from experts outside the U.N. process. See LEWIS, supra note 108.

${ }^{228}$ Of these states, only four retain the geographic restriction to refugees in Europe: Turkey, Congo, Madagascar, and Monaco. Madagascar, Monaco, and St. Kitts and Nevis also retain the temporal restriction to refugees since 1951.

${ }^{229}$ Gil Loescher, UNHCR AND World Politics: A Perilous PATH, (2001), at 80.

${ }^{230}$ See, e.g., James C. Hathaway \& R. Alexander Neve, Making International Refugee Law Relevant Again: A Proposal for Collectivized and Solution-Oriented Protection, 10 Harv. Hum. RTS. J. 115 (1997); Peter H. Schuck, Refugee Burden-Sharing: A Modest Proposal, 22 YAle J. INT'L. L. 243 (1997); Deborah Anker, Joan Fitzpatrick \& Andrew Shacknove, Crisis and Cure: A Reply to Hathaway/Neve and Schuck, 11 HARV. HuM. RTS. J. 295 (1998). 
guidance to states facing mass influxes of refugees, which overwhelm state processing capacity, even in wealthier states. Critics have also noted that the Convention relies on displacement outside the state as a solution to refugee problems rather than requiring the international community to address the systematic cause of refugee outflows. After all, the Convention imposes no requirement for states not to persecute or expel their citizens; it merely guarantees them certain rights if they are able to flee to a signatory country. Divergent application of the term "refugee" from state to state sows confusion in the community of asylum-seekers and encourages irregular migration, often linked to human smuggling and related criminal enterprises. Because the Convention requires refugees to flee their countries of origin to be accorded rights, those without means to flee may actually be the most vulnerable and remain unprotected.

The lack of provisions for international burden-sharing in the 1951 Convention leaves poor states, which house most of the world's refugees, especially vulnerable to conflict spillover when refugees flood into their borders. Most of the world's refugees originate and are displaced within Africa and the Middle East, where the majority of countries are not signatories to the Convention. Even in countries in these regions that are Convention signatories, asylum regimes are often weak or absent, which means most of the world's refugees have no legal basis on which to rely for protection. In recognition of the defects in the 1951 Convention, regional legal instruments, such as the Organization for African Unity and the Cartagena Declaration, have adopted definitions of "refugee" that encompass persons fleeing violence in addition to the Convention's narrow persecution grounds. ${ }^{231}$

\section{THE FAILURES OF INTERNATIONAL REFUGEE LAW}

Since the Convention has become less useful to protect displaced people, refugee protections have been increasingly less legalized over time. UNHCR has largely become a humanitarian aid organization rather than a legal protection agency. ${ }^{232}$ Since the end of the Cold War, the Agency has focused more of its budget and organizational priorities on operations rather than on legal protection, which has been quite controversial. One senior protection officer explained to me that "Protection means something specific" under international law, and it is eroded each time UNHCR waters

231 See OAU Convention, supra note 215. The non-binding Cartagena Declaration contains a similar definition. See CARTAGena DeClaration on REFugeES, Colloquium on the International Protection of Refugees in Central America, Mexico and PANAMA, 22 November 1984.

${ }^{232}$ LOESCHER, supra note 229. 
it down to aid new categories of people. ${ }^{233}$ However, others within the organization believe the shift in focus from legal protections to humanitarian aid enables them to assist more people. As a Senior Adviser to the High Commissioner explained to me in 2010, while international law underpins the Agency's work, it is often better to get things done rather than "banging the bible." 234

The Agency has extended its operations far beyond those specified in its Statute or the Convention. As need has arisen, the U.N. Secretary General has designated additional people to fall within UNHCR's "persons of concern," including select groups of internally displaced people. 49.2 million people fell under the Agency's mandate as of 2013, but only about 11.7 million are Convention refugees. ${ }^{235}$

Unfortunately, however, UNHCR's role has become increasingly politicized. After a number of budgetary crises, UNHCR has survived by making itself an agent of the world's major powers. ${ }^{236}$ The Agency's mandate must be regularly renewed by the U.N. To continue its existence, UNHCR must appear responsive to the needs of its donors, accountable to them, and efficient in achieving their goals. Because the agency receives 93\% of its budget from state donors, it is almost completely dependent on individual donor countries for its survival. The $7 \%$ of its budget that comes directly from the U.N. mostly pays for overhead. UNHCR is especially dependent on the U.S. for funding. The U.S. has consistently been the UNHCR's single largest donor, typically funding about 30\% of UNHCR's budget. ${ }^{237}$ The European Commission, its member states, and Japan typically account for most of the remainder of the budget. The U.S. and EC exclusively earmark their contributions to UNHCR to ensure that the Agency serves their foreign policy goals. In 2010, only $16.5 \%$ of the Agency's total contributions were un-earmarked. ${ }^{238}$ The Agency's operations, then, are a function of the political interests of those states that fund it.

De-legalization of the refugee regime has meant increasing politicization of refugee assistance. UNHCR has increasingly acted at the behest of the wealthy states that provide its funding. ${ }^{239}$ To give but a few

\footnotetext{
${ }^{233}$ Interview with Petros Mastakis, Protection Officer, UNHCR-Syria, in Damascus, Syria, (Jan. 6, 2010).

${ }^{234}$ Interview with Jose Riera, Senior Policy Adviser to the High Commissioner, UNHCR, in Geneva, Switz. (June 18, 2010).

${ }^{235}$ UNHCR Global Trends 2013, supra note 3.

236 On agency in international organizations, see generally DARREN G. HAWKINS ET AL., Delegation AND AgEnCy In InTERnAtional ORgANiZATIONS (2006).

${ }^{237}$ BETTS ET AL., supra note 22 at 97-98.

${ }^{238} \mathrm{http}: / / \mathrm{www}$. unhcr.org.

239 In other work, I document how the Agency has expanded and contracted the
} 
examples, the Agency expanded its mission for the first time to include internally displaced people in the early 1990s to assist nearly all of those displaced due to the disintegration of the former Yugoslavia. This radical expansion of the Agency's mission was done at the behest of European powers that wished to keep Muslim immigrants from entering into Europe. ${ }^{240}$ In the early 1990 s, at the direction of the U.S., the Agency also assisted Kurds who were internally displaced within Iraq, in part to ensure that they did not flee into neighboring Turkey, a U.S. ally. ${ }^{241}$ After the U.S. invasion of Iraq in 2003, a "prima facie" refugee regime was adopted to term nearly all Iraqis who had fled to neighboring countries as "refugees." This allowed them to receive assistance from UNHCR and increasing the probability that they would receive humanitarian assistance from the international community, regardless of whether they met the 1951 Convention definition of "refugee."

Meanwhile, increasingly restrictive domestic asylum regimes, particularly in the West, have narrowed the reach of the 1951 Convention. States have defined persecution narrowly, requiring refugees to prove a specific fear of persecution, or to return to dangerous conditions in their countries of origins to provide identity documents in order to be resettled. ${ }^{243}$ Elsewhere, states have refused to winnow refugees from "mixed flows" containing refugees and migrants, instead sending all would-be asylumseekers to return to their home countries. ${ }^{244}$ In the 2000 s, the European Union revamped its asylum regime with a series of laws designed to discourage migration by sending asylum-seekers back to their original country of entry within Europe, and building massive detention centers in Italy and Greece, the most frequent points of first entry, to house them

definition of refugee to serve the interests of its donor states, particularly the U.S. See Jill Goldenziel, supra note 24 (documenting expansion of the term refugee to encompass most Iraqis fleeing after the U.S. invasion of 2003); JILL GOLDENZIEL, DisPLACED: REFUGEES, INTERNATIONAL LAW, AND U.S. FOREIGN POLICY (forthcoming).

${ }^{240}$ LOESCHER, supra note 229.

${ }^{241}$ Jeff Crisp et al., "Review of UNHCR Emergency Preparedness and Response in the Persian Gulf Crisis," UNHCR, March 1992; Humanitarianism and War Project, "United Nations Coordination of the International Humanitarian Response to the Gulf Crisis, 199092," Brown University and Refugee Policy Group (June 1992). The latter report was commissioned by the Geneva Office of the U.N. Department of Humanitarian Affairs.

${ }^{242}$ See generally Goldenziel, supra note 24.

${ }^{243}$ For example, Iraqi refugees in 2006 and 2007 were required to return to Iraq to retrieve identity documents, often at great personal risk given pervasive civil conflict and rampant persecution on the basis of religion.

${ }^{244}$ See generally United Nations Office of the High Commissioner for Human Rights, Report of the detailed findings of the commission of inquiry on human rights in the Democratic People's Republic of Korea -A/HRC/25/CRP.1 (2014) (discussing China's policy of summarily repatriating escapees from North Korea). 
while they ostensibly await processing. In 2004, the European Union also created a new, extensive border patrol agency called Frontex to patrol Europe's borders. ${ }^{245}$ Frontex's interdiction of migrants at sea and sending them back to their home countries has caused NGOs to accuse them of refoulement. ${ }^{246}$ Increasingly Western states have employed restrictive visa requirements, carrier sanctions, "safe third country" designations, "readmission agreements," and internal "safe zones" inside conflict areas to prevent asylum-seekers from crossing borders. ${ }^{247}$ While UNHCR has protested many of these measures, there is little they can do to stop them.

Thus, despite its drafters' intentions to create a Convention that is universal in its application to all refugees, international refugee law is hardly applied universally. While human rights were a paramount concern of many of those who negotiated the treaty, power politics intervened then and throughout the development of international refugee law. Today, UNHCR primarily assists displaced people who impact the security interests of the wealthier states who fund its operations, regardless of their status under international law. Meanwhile, many of these same wealthy states have been increasingly restricting entry to refugees using tactics that may even violate the Convention. To provide refugees with the human rights protections that the Convention's drafters intended, while protecting the rights of sovereign states, new international law is needed.

\section{Toward A New Displaced Persons Convention}

As James Hathaway has noted, refugee status has always taken on "different meanings as required by the nature and scope of the dilemma prompting involuntary migration." 248 But even as the scope of involuntary migration has radically changed over the course of the past sixty years, refugee status in international law has remained static. As noted above, scholars and policymakers have repeatedly argued that international refugee law is irrelevant to the world we now face.

How can international law better protect the human rights of refugees while also protecting states? There has been great debate over

245 Frontex was authorized by (EC) 2007/2004. Frontex became operational on October 3, 2005.

${ }^{246}$ See, e.g., "NGO Statement on International Protection: The High Commssioner's Dialogue on Protection Challenges," UNHCR ExCom Standing Committee, $41^{\text {st }}$ Meeting, March 4-6, 2008. On interdiction at sea and refoulement, see Jill Goldenziel, When Law Migrates: Refugees in Comparative International Law, in Paul Stephan, eds., COMPARATIVE INTERNATIONAL LAW (forthcoming, Oxford University Press, 2015).

247 Anker, et al., supra note 230, at 297.

${ }^{248}$ Hathaway, supra note 49, at 380. 
exactly how to reform the international refugee regime. Roughly speaking, proposals to reform international refugee law have been either moral or economic in nature. Michael Walzer and Niraj Nathwani, for example, have argued that assistance to refugees should be based on need. ${ }^{249}$ The moral obligation to assist people based on need rather than on persecution on the basis of particular categories, they argue, is equivalent, and therefore the category of "refugee" should expand beyond the narrow Convention definition to all people forced to migrate and in humanitarian need. Other scholars have called for a broadening of the definition of the term refugee. Joseph Carens argues that, from a moral perspective, the Convention definition should be revised so that "the seriousness of the danger and the extent of the risk, not the source of the threat or the motivation behind it," matters most. Selya Benhabib, argues that Kant's "universal right to hospitality" imposes upon states a moral duty to assist anyone "whose life, limb, and well-being" are endangered, implying the need for a broader definition of the term "refugee." 250 Most broadly, liberal and utilitarian theorists have argued that not only are states morally required not to refoul those who would have their lives endangered, but that they are obligated to accept larger numbers of refugees and immigrants; categories which they often conflate, since they often do not use the term refugee in the legal sense. Joseph Carens and Anne Dummet, for example, argue that liberalism requires that states recognize a right to freedom of movement that would require them to accept all those who wish to live there. ${ }^{251}$ Peter and Renata Singer argue that liberal democracies are obligated to accept refugees up until the point that tolerance in the society would break down, endangering peace and security. ${ }^{252}$

Economic proposals to reform the 1951 Convention, by contrast, focus on the burden-shifting necessary to align state interests with greater international protection. While the details of these proposals vary significantly, most scholars seem to agree that they must focus on burden-

\footnotetext{
${ }^{249}$ Michael Walzer, Spheres of Justice: A Defense of Pluralism and Equality (1983); NiRAJ NATHWANI, RETHINKING REFUGEE LAW (2003), at 7.

${ }^{250}$ Selya Benhabib, The Rights of Others: Aliens, Residents, and Citizens (2004), at 37.

${ }^{251}$ Joseph Carens, Migration and Morality: A Liberal Egalitarian Perspective, in Brian Barry and Robert Goodin, eds., Free Movement: ETHICAL ISSUES IN THE Transnational Migration of People and Money (1992), at 25-47; Anne Dummett, The Transnational Migration of People Seen from within a Natural Law Tradition, in Brian Barry and Robert Goodin, eds., FREE MOVEMENT: ETHICAL ISSUES IN THE Transnational Migration OF PeOPle and Money (1992), 169-80.

${ }^{252}$ Peter Singer and Renata Singer, The Ethics of Refugee Policy, in Mark Gibney, ed., OPEN BORDERS? ClOSED SOCIETIES?: THE ETHICAL AND POLITICAL ISSUES (1988), at 11130 .
} 
sharing and outcome-based solutions that focus on displacement as it currently exists rather than the Convention definition of refugee. ${ }^{253}$ Two of the most prominent proposals, developed in the late 1990s by James Hathaway and Alexander Neve, and by Peter Schuck, argued for insurancelike schemes to incentivize Northern states to reduce the costs of processing migrants by shifting costs to Southern states that would serve as countries of first asylum. ${ }^{254}$ Hathaway later acknowledged that these policies attracted little attention from the policymaking community and were roundly criticized by other refugee scholars. ${ }^{255}$ Among other flaws, scholars charged that the proposals accepted the current policies of Northern states to dodge the obligation of non-refoulement, failed to solve many of the inherent flaws in the current refugee regime, and advocated for group-based rather than individualized processing for refugees. ${ }^{256}$

Other, atomistic proposals have developed to assist certain groups of migrants, such as climate change migrants. ${ }^{257}$ However, addressing only one group of non-persecuted forced migrants only creates further confusion in the application of international law. Such proposals further segment the problem of forced migration and do not account for the needs of states to address the overall burden that all types of forced migration place on their own domestic security and asylum systems. Moreover, such proposals are based on group claims for international protection, rather than on the individualized claim processing that human rights concerns demand.

Recognizing the problem of population displacement beyond the plight of refugees, some countries have made regional agreements to address these issues. These efforts have largely failed. The 1969 OAU Refugee Convention and 1984 Cartagena Declaration for Refugees in Latin America expand the definition of refugee to include people who have fled violent conditions or disturbances in public order. ${ }^{258}$ However, both documents are non-binding, states have been slow to incorporate them into

${ }^{253}$ See HathawAy, id.

${ }^{254}$ Hathaway and Neve, supra note 230; Schuck, supra note 230.

255 James C. Hathaway, Book Review: Rethinking Refugee Law, by Niraj Nathwani, 98 AM. J. INT'L L. 616 (2004), at 616.

${ }^{256}$ For the most prominent critique, see Anker, et al., supra note 230.

${ }^{257}$ Katrina Miriam Wyman, Responses to Climate Migration, 37 HARV. EnvTL. L. REV. 167 (2013) (discussing three recent proposals for international legal and non-legal responses to climate change migration); Agnes Hurwitz, Climate-Related Displacement: The Perilous Path Towards Normative Development, in Susan Akram and Tom Syring, eds., Still Waiting For Tomorrow: The LAW And Politics of UnResolved RefugeE CRISES (2014).

258 See, e.g., Organization for African Unity, supra note 215; CARTAGENA Declaration on Refugees, Colloquium on the International Protection of Refugees in CENTRAL AmericA, MeXico And PANAMA, 22 November 1984. 
their domestic law, and they include no burden-sharing mechanisms. EU Directives, most recently a set of 2011 Directives meant to be adopted in June 2015, are largely focused on curbing migration, although they do allow for "subsidiary protection" for people fleeing generalized conditions of violence who do not qualify for refugee status. ${ }^{259}$ Recent caselaw shows that EU states are not following the directives, and many states have opted out of the most recent Directive. Temporary Protection (TP) regimes have been adopted by some states in response to humanitarian emergencies. However, TP regimes are applied haphazardly, sow confusion by differing from state to state, and arguably have been used by countries to avoid their obligations under the 1951 Convention. $^{260}$ The "Deng Principles" on internal displacement are not binding and are left to individual states to adopt in their own policies and caselaw, and do not address the root causes of displacement that may cause both internal and external displacement. ${ }^{261}$ None of these documents deal with all of the causes of modern flows of displaced people that have threatened international peace and security. Moreover, the protections associated with all of these documents are ambiguous because of terms left undefined, lack of state will or capacity, or because such non-binding regional agreements may clash with the aims of the 1951 Convention.

\section{A. Why International Law?}

What is the role of international refugee law in a modern migration environment at all? When proposing reforms for international law regarding refugees and displaced persons, this foundational question is necessary to consider. After all, senior officials in UNHCR, including the High Commissioner, have found that politically palatable solutions to displacement crises are often policy-based and not legal. ${ }^{262}$ Most refugee crises, and indeed, most forced migrants, are in the developing world, where domestic asylum regimes are weak or absent, as is adherence to international law and international human rights law in particular. In states averse to international law, UNHCR often finds that pushing states to

${ }^{259}$ EU Directive 2011/95/EU.

260 Joan Fitzpatrick, Temporary Protection of Refugees: Elements of a Formalized Regime, 94 AM. J. INT'L L., 279, at 298; European Council of Refugees and Exiles, Position of the European Council on Refugees and Exiles on Temporary Protection in the context of the Need for a Supplementary Refugee Definition, available at http://ww.ecre.org.

261

${ }^{262}$ Interview with Antonio Gutierres, High Comm'r, UNHCR, in Geneva, Switz. (July $30,2010)$ 
comply with international legal obligations does not work, and it needs to find other solutions to assist refugees. As senior UNHCR officials explained to me, solutions that work are most easily found through bilateral negotiations for aid between donor and recipient states, or by emphasizing the humanitarian nature of a situation instead of legal commitments. ${ }^{263}$

However, international law to protect refugees and other displaced people is still necessary. International law solves several collective action problems that are important for the protection of both human rights and state security. A binding, international framework is necessary to keep states from adopting policies that collectively harm asylum-seekers.

First, international refugee law provides a floor for state migration policies. Eric Posner and Adam Cox have recognized, in their discussion of an optimal migration contract, that refugee rights require international cooperation to avoid a "race to the bottom," in which states adopt increasingly restrictive refugee policies to deflect refugees to other states. ${ }^{264}$ Only international law can ensure that these refugees have somewhere to turn.

Moreover, the Convention does provide some legal protection to many people in need. In states that have signed the Convention, UNHCR uses the Convention as a basis for its operations, and as a starting point for negotiations on what it can do in a given state. As Deputy Representative in Egypt, Katharina Lumpp explained to me, the Convention serves as a basis for negotiation on the treatment of refugees in state signatories. When states have signed the Convention, UNHCR has a framework upon which to draw. ${ }^{265}$ International refugee law provides a floor for refugee protection in all of its state signatories, and a baseline for negotiation for increased protection.

On a broader level, international human rights law, including international refugee law, has always served an important aspirational purpose. Although most of the world's states are signatories to either the ICCPR or the ICESCR - which are known, along with the Universal Declaration of Human Rights, as the international bill of rights - no signatory no truly lives up to all of the commitments it has made in either document. The rights that these documents seek to entrench are so broad

${ }^{263}$ Interview with Jose Riera, supra note XX; Interview with Antonio Gutierres, id., Interview with Dag Sigurdson, Deputy Head, Donor Relations \& Resource Mobilization Unit, UNHCR, in Geneva, Switz. (Jul. 21, 2010).

264 Adam Cox and Eric Posner, The Rights of Migrants: An Optimal Contract, 84 N.Y.U. L. REV. 1403,1462; see also Ryan Bubb, Michael Kremer, and David I. Levine, The Economics of International Refugee Law, 40 J. LEG. STUD. 367-404 (2011) (describing a race to the bottom).

${ }^{265}$ Interview with Katharina Lumpp, Deputy Representative, UNHCR-Cairo, in Cairo, Egypt (Dec. 10, 2009). 
and so vague that no signatory can possibly live up to the ideals they contain, and full realization of these rights would also be impossible due to inevitable clashes between the ideals they embody. Yet these documents provide important aspirational norms for states, which commit to each other, in an international forum, that they will keep trying to live up to these utopian standards. Indeed, these documents contain clauses that commit developing states to continued improvement toward these ideals, even if they cannot currently comply with them. So long as states continue to aspire to these international norms, they will continue to seek justice and human rights for all of their citizens. Much like constitutional law on the domestic level, international human rights law serves to entrench certain precommitments that cannot be violated, regardless of majority will. ${ }^{266}$ As states increasingly adopt international human rights law as a basis for their own constitutional instruments, enabling litigation and interpretation of these norms in domestic courts, their importance as foundations of law continue to increase.

International refugee law reinforces other normative goals of the international human rights system. The Genocide Convention, Convention on the Elimination of Racial Discrimination (CERD), and Convention Against Torture and Other Cruel, Inhuman or Degrading Treatment or Punishment (CAT), all proscribe categories of behavior related to those in the 1951 Convention. The International Bill of Rights also contains provisions entrenching an international human right to freedom of expression, which includes the right to express political opinions without persecution. ${ }^{267}$ The existence of refugees is often a sign that serious human rights abuses are occurring within a state, such as genocide or ethnic cleansing. Multiple international human rights commitments are mutually reinforcing and help ensure that states will be continually vigilant against human rights abuses.

\section{B. Preserving the 1951 Convention Definition of "Refugee"}

The current definition of "refugee" in international law should not be modified. As an instrument of international human rights law, the core commitments entrenched in international refugee law remain as relevant and important as ever. As the historical record shows, members of racial, religious and ethnic minority groups are as likely as ever to be persecuted

\footnotetext{
266 On parallels between international and constitutional law, see Jack Goldsmith \& Daryl Levinson, Law for States: International Law, Constitutional Law, Public Law, HARV. LAW REV. 1791-1868 (2009).

${ }^{267}$ ICCPR Article 19.
} 
on the basis of these characteristics. Protection of people on the basis of these categories is worth preserving, as states have repeatedly been incapable of providing protections for individual members of these groups. Persecution of minorities is often systematic and not easily solved. International refugee law provides that these people must be given basic human rights even when their countries of origin cannot provide them; that a certain minimum level of human rights indeed normatively exists outside the state. International refugee law is truly international- law that extends beyond the traditional zone of state sovereignty to obligate states to provide legal protections for non-citizens who are de facto without the protections of their countries of origin. International refugee law provides an important function for protecting the rights of those whom the international community has deemed the most vulnerable: members of religious, racial, and ethnic minorities, as well as members of particular social groups, such as homosexuals. Even as the category of those persecuted on the basis of political opinion has changed over time, the international community has, on a normative level, always been concerned with the protection of minority rights. As the protection of minority rights is fundamental to democratic systems, any international legal system seriously concerned with democratic values must protect them as well.

\section{Refugees are Unique Among Displaced People}

Refugees are distinct from many other groups of forced migrants because they are unable to avail themselves of the protection of their states due to their fear of persecution. Unlike refugees, forced migrants have not had their ties to their states severed by persecution or fear of it. Other groups of forced migrants, such as those leaving their countries due to generalized violence, economic blight, or climate change, may have a government that is very much interested in providing them with some legal protections. Whether displaced inside or outside their country, these people still enjoy the benefits of citizenship, including freedom to travel and freedom of movement, which bona fide refugees do not enjoy. They may be able to migrate to other sections of their country, where they can enjoy these protections, without moving abroad. The governments of climate change migrants, in particular, may be actively working toward a solution to protect their citizens. Governments can seek assistance from the international community on behalf of their citizens.

Refugees are unlike other displaced people precisely because of their inability to enjoy the benefits of citizenship due to their fear of persecution, and their specific needs demand a specific solution. Refugees do not have equivalent needs to other types of forced migrants. For forced 
migrants, resolution of conflict within the state, or recovery from the natural disaster that caused their displacement, may end their displacement. Their displaced status depends on the resolution of the conflict within the state. For refugees, this is not enough. The nature of the persecution that caused the flight is dependent on both nature of the state and the individual involved. Resolution of conflict or disaster within the state will not be enough for the bona fide refugee. Just as it would have been ludicrous to expect all Jews to return to Germany after the end of World War II, it would be abhorrent to expect all refugees who have fled persecution to return to their countries of origin.

The equivalent humanitarian need of other groups of forced migrants does not demand the same type of solution. Refugees require legal complementarity - legal protections ordinarily provided by states because states are unavailable to provide these basic needs. Historically, a primary function of international refugee law was to provide refugees with passports, travel documents, and certifications of personal status that states were unable to provide them. Although UNHCR today is more an international humanitarian agency than a legal one, these basic legal protections remain among its most critical functions. Refugees also need the right to work and access justice required by international refugee law, because their states are unavailable to provide them with these basic needs. Other types of migrants may still be available to avail themselves of the protections of their states, including work permissions. Also, aid may be available to them within the state, within their region of origin, or without the necessity of permanent resettlement. Persecution on the grounds enumerated in the 1951 Convention is among the most egregious of human rights abuses. Refugees present the most serious case of need because of their most vulnerable political circumstances. Morality does not require prioritization of the more materially destitute.

Changing humanitarian needs should not change the core definition of what constitutes a human right. The right of freedom from persecution on the basis of one's religious, racial, ethnic, or national status, or political opinion, is one that has been entrenched in international law before the advent of modern law itself. Expanding the category of "refugee" to include other groups of displaced people would undermine the protections that states long ago determined to be in their moral and political interests, along with well-established law that has given legal protections to generations of people without anywhere else to turn. ${ }^{268}$

While sovereign states legitimately have the right to restrict their

${ }^{268}$ Joseph H. Carens, Refugees and the Limits of Obligation, PUBLIC AFF. Q. 31-44 (1992). 
borders, this does not mean that states have no moral obligation to admit as many or as few applicants who would like to live there. States need principles for whom to prioritize for entry. International refugee law provides states with a universal rubric for whom to prioritize. People who are persecuted on the basis of religion, race, nationality, or membership in a particular social group may be prioritized in the international system, since they face needs that make them unique from other members of the international community.

2. The Expressive Importance of Preserving the Refugee Definition

International refugee law as it currently exists provides a powerful expressive function. By categorizing victims of persecution on the basis of race, religion, nationality, political opinion, or membership in a particular social group as in need of international protection, the international community has effectively proscribed certain behaviors as beyond the pale of what it can accept. The term "refugee" holds tremendous rhetorical power. The term "displaced person" connotes mere movement of a person from one place to another due to any number of circumstances. "Refugee," by contrast, is a term that defines a specific set of commitments that the international community has historically owed to a person. "Refugee" also connotes humanitarian need worthy of international assistance. The strategic use of these terms by actors in the international community can support or detract from their own political aims. A country cannot produce large numbers of "refugees" unless conditions inside it are unstable. Countries may also suffer reputation losses from expelling "refugees," or by failing to admit those who claim to be "refugees." Conversely, asylum countries are likely to gain reputational benefits from hosting "refugees." Defining a group of displaced people as "refugees" also affects the way that other political actors will treat population movement.

The existence of the category of "refugee," as it stands, plays another important expressive role by implicitly condemning certain state behaviors. Refugee status connotes the failure of states to protect their own citizens; more particularly, the failure of governments to do so. Indeed, refugee status implies a human element that other types of forced migration do not. Refugees flee when states are involved in persecution or are unable or unwilling to protect individuals from persecution occurring within their borders. Other categories of migrants may be fleeing the vicissitudes of fortune, perhaps wrought by Mother Nature, but not necessarily due to state action. The existence of refugee law casts aspersion upon the behavior of states that fail to protect their own citizens, and more so in the case of states that are unwilling to do so. Such a basic failure of the function of a 
government calls the legitimacy of that state or government into question.

This expressive function is increasingly important in the context of recent international debates over when sovereignty can be violated to protect human rights, embodied by controversies over the Responsibility to Protect and appropriate uses of the International Criminal Court. ${ }^{269}$ The Security Council has linked the prevention of refugee flows and population displacement, considered a threat to international security, as justification for recent international interventions in Haiti, Iraq, Kosovo, Liberia, Rwanda, and Somalia. ${ }^{270}$ In the context of increased willingness by the international community to violate sovereignty to protect human rights, it is especially important not to back away from international refugee law, which has long guaranteed rights that individuals have independent of states. Having such a category in international law sends a message to states that their behavior in persecuting religious and ethnic minorities, and individuals who express minority political opinions, will not be tolerated by the international community.

\section{The Need for a Displaced Persons Convention}

Do non-refugees deserve protection by states? Both moral and practical reasons suggest the answer is yes. The special obligation to protect refugees does not absolve states of a moral responsibility to protect other groups of displaced people. On moral grounds, the philosophical principle of mutual aid requires that if a person is in dire need and a state is able to assist that person with little cost, a state has a moral duty to help them. ${ }^{271}$ Moral concerns may be heightened when neighboring states bear some responsibility for the circumstances of displacement, such as international involvement in civil conflict, or climate change to which industrialized states have contributed. Even for states who reject morality principles on sovereignty grounds, practicality mandates international assistance for people who fall outside of the Convention definition of refugee. States benefit from stability and predictability in the international system, and suffer from having their borders flooded by those seeking to leave desperate circumstances elsewhere, whatever the cause of their flight. States also suffer when vulnerable people compete over scarce resources, often causing conflict that can spill over state borders. Population displacement is a

\footnotetext{
${ }^{269}$ See, e.g., Secretary General, IMPLEMENTING THE RESPONSIBILITY TO PROTECT: REPORT OF THE SECRETARY-GENERAL (2009) A/63/677.

${ }^{270}$ Guy Goodwin-Gill, 'Editorial: Refugees and Security', INT’L J. REFUGEE LAW, vol. 11, no. 1, 1999, 3; Alan Dowty \& Gil Loescher, Refugee Flows as Grounds for International Action, 21 INT. SECUR. 43-71 (1996), 39-40.

${ }^{271}$ WALZER, supra note 249, at 49-50.
} 
problem of international scope and ramifications that demands an international solution.

Binding international law is needed to simultaneously protect both the interests of states and displaced people. Mere legal standards and best practices will not suffice given the scope of the problem; the international community must pre-commit to an assistance framework to help these people retain their basic right to human dignity, regardless of the circumstances of their flight. Without binding law, states will likely have the incentive to shirk their duties when international politics dictate that they do so, due to domestic political constraints or failure of their immigration systems. International law also provides important guidance to the international community, even to non-signatory states, on how to manage population displacement. Currently, even in states that have not signed the 1951 Convention, UNHCR uses the Convention and state practice, along with states' other commitments to international human rights law, as leverage to pressure states to protect displaced people. Moreover, the existence of international law reduces the possibility that assistance will be politicized in the future. With international agreement on how to protect displaced people, and who should be categorized as displaced people, the international community will be less able to ignore displaced populations or to choose to aid them selectively based on political will.

\section{Outlining the Category of "Displaced Persons"}

Given the need for international cooperation to define displaced persons, the goal of this section is not to draft a new international legal instrument. To do so would be naïve. Ultimately, all international law must be negotiated and bargained-for by states. No new international legal framework can be expected to succeed without such negotiation by states and other stakeholders. This article's goal is simply to sketch some considerations for states as they negotiate new protections to protect displaced people while preserving their own sovereign aims and protecting their borders. A Displaced Persons Convention must involve provisions for definition of the category of displaced people, preventative measures to protect against flows of displaced people, as well as procedures for funding and implementation. I will discuss each of these categories briefly below.

\section{Defining Displaced Persons}

State parties must negotiate the definition of "displaced persons" to ensure that the definition reflects both state sovereignty and human rights concerns. The definition must be carefully crafted to avoid encompassing 
endless flows of people. It must exclude economic migrants and others who could be directed to a state's regular immigration system. The international community should protect only those flows of displaced people whose flight threatens international peace and security, in accordance with the language of Article I of the U.N. Charter. States will be interested in providing protection if international stability is threatened. While this standard is less stringent than the "well-founded fear" of the 1951 Convention, it also ensures that all individuals will not have a claim to be "displaced people."

As a starting point for the definition of "displaced person," the international community might draw lessons from the definitions promulgated by the Organization for African Unity and the European Community in their attempts to provide protection to those who do not meet the Convention definition. The OAU Refugee Convention defines a "refugee" as: ${ }^{272}$

every person who, owing to external aggression, occupation, foreign domination or events seriously disturbing public order in either part or the whole of his country of origin or nationality, is compelled to leave his place of habitual residence in order to seek refuge in another place outside his country of origin or nationality.

The 2011 EU Directive provides "subsidiary protection" to those who can show "substantial grounds ... for believing that," if returned to his country of origin or former habitual residence, he "would face a real risk of suffering serious harm ... [and] is unable, or owing to such risk, unwilling to avail himself or herself of the protection in that country." ${ }^{273}$ The directive defines "serious harm" as "(a) death penalty or execution; or (b) torture or inhuman or degrading treatment or punishment of an applicant in the country of origin; or (c) serious and individual threat to a civilian's life or person by reason of indiscriminate violence in situations of international or internal armed conflict." 274

Both definitions expand the category of persons who should receive international assistance in a way that would not create endless obligations for states. The OAU definition focuses on the causes of displacement, while the EU's definition focuses on the risk of harm that an individual will face

${ }^{272}$ Organization for African Unity, supra note 215.

${ }^{273}$ European Council Directive 2004/83, On Minimum Standards for the Qualification and Status of Third Country Nationals or Stateless Persons as Refugee or as Persons who Otherwise need International Protection and the Content of the Protection Granted, 2004 O.J. (L304) 12 (EC), art. 2(e).

${ }^{274}$ Id., Art. 15(a)-(c). 
if refouled. The OAU's mention of "external" or "foreign" pressures implies that international involvement in a displacement logically is required for an international response to occur. The events must be "seriously disturbing public order," which is close to the level of threatening international peace and security. Moreover, displaced persons must be "compelled" to leave their place of habitual residence in order to seek refuge outside of his country. This standard, while less stringent than the specific fear of persecution required by the 1951 Convention, still demands that people are forced to migrate for reasons other than personal convenience, and would exclude economic migrants. "Compelled" implies that displaced people find it necessary to flee their homes because their states cannot provide adequate protection in a particular instance. Combining this definition with the EC's requirements that a specific, individualized risk of harm restricts the definition further. Including the EC's criteria ensures that the focus of protection will be on individuals, rather than groups of displaced people.

The OAU and EC definitions, while imperfect, provide important guidance for protecting both individuals and states. No doubt, they will not satisfy the theorists discussed above who seek to expand the category of refugee more broadly. However, put together, the OAU Convention and the EC Directive sketch out a definition of "displaced person" likely to be accepted by states. At the core of both is the norm of non-refoulement, the idea that a person must not be sent back to a place where her life would be endangered. Together, both documents protect individuals fleeing for reasons beyond the stringent standards of the 1951 Convention while ensuring that the definition of displaced person will not become so broad as to be meaningless and require international protection for anyone in need of humanitarian assistance. State practice, or at least the intent of states in Africa and Europe, lies behind these definitions as well. A broader commitment to a similar definition by states would not therefore result in a problematic rollback of international aid and legal protections from many who currently receive them. Given quickly changing migration flows, any definition of Displaced Persons should be revisited by states parties every few years, which would allow states to respond to new migration challenges facing states.

\section{Preventative Measures}

International law defining a category of displaced persons should require states to implement preventative measures in order to receive a guarantee of future international assistance. States cannot necessarily predict that their countries will erupt in civil conflict. However, they can tell 
if they are situated in a bad neighborhood, where surrounding states are prone to instability and strife. Many can also foresee potential displacement resulting from climate change issues, which often take years to develop. States in the global North can often predict whether and how such issues will affect their borders, on the basis of how past episodes of international violence and climate change have impacted their immigration and border controls. An international legal framework could pre-commit states to responding to these future needs. It could also commit states to allowing safe zones for displaced people to be established by the international community within their borders in the event of civil conflict or climate change displacement, which would help stem the flow of displaced persons elsewhere. It could also ensure that peace treaties to which states are parties or help negotiate will include provisions for safe return of refugees and displaced people. The treaty should also stipulate reporting mechanisms to allow the international community to plan for displacement before it occurs.

The Convention should also commit states to allow an international body to implement an information campaign designed to avoid misconceptions about who qualifies as a displaced person, and the assistance and protection that displaced people while receive. In the late 1980s, as part of the Comprehensive Plan of Action to end the Indochinese boatpeople crisis, UNHCR set up an information campaign on television in Vietnam. The advertisements showed scenes of adequate, but not deluxe, refugee camps in Hong Kong and elsewhere, and featured interviews with UNHCR personnel discussing the refugee status determination process, and explaining how those who did not qualify would be sent back to Vietnam. The advertisements were designed to present Vietnamese people with neutral facts that would enable them to make an informed decision about whether to leave their country. The ads are credited with wildly reducing flows of "boat people" from both North and South Vietnam. ${ }^{275}$ Similar information campaigns might be useful in reducing flows of displaced people to Europe and elsewhere today. Displaced persons should know that they would only be granted temporary protection until sufficient arrangements can be made for them to return to a safe zone within their country of origin, and that such protection could end at any time. Only Convention refugees would receive access to resettlement and local integration options. Displaced persons should also know what work, housing, and other opportunities will be available to them if they should choose to flee their countries.

${ }^{275}$ Luise Druke, Innovations [CITE]; Cassella 
3. Funding

An international legal framework to protect displaced people must also include provisions for financial burden sharing among states. ${ }^{276} \mathrm{~A}$ full discussion of burden-sharing mechanisms lies beyond the scope of this paper, and would require economic analysis of whether the costs of a new Displaced Persons Convention would be less than the current strains on host countries' asylum and coast guard systems. However, the U.N.'s own best humanitarian practices dictate that a common pool of humanitarian aid money should be created and reserved for deployment in emergency situations. States could commit to funding an international fund for displaced people, similar to the fund underlying the Global Counterterrorism Forum. The fund could be administered by UNHCR or another body to provide protection and assistance for displaced people. This commitment would help rectify the funding gap that has been identified as a weakness in other proposals to assist displaced people. ${ }^{277}$

Both wealthier and poorer states would be incentivized to participate in this fund. Wealthier states would benefit from participation by reducing the infrastructural, financial, and security challenges they now face from large groups of displaced people reaching their shores through legal and illegal migration channels. Poorer states would be incentivized to sign on because of the potential for receiving Western funds to assist displaced people who are likely to flood into their borders due to dire circumstances of all sorts. Western states could agree to shift funds currently designated for domestic asylum processing to provide humanitarian aid for displaced persons abroad, while poorer states would provide safe areas for protection of refugees, whether in urban settlements or in refugee camps. States would not be forbidden from pursuing their own foreign policy objectives, such as giving additional development aid to their allies or strategic partners. However, a fund would provide baseline financial assistance and a minimum commitment to burden sharing by the international community. UNHCR would likely welcome such a framework because it would save them from needing to undergo complicated legal and administrative contortions to protect large "mixed migration" flows containing both refugees and non-refugees, and would provide them a foundation on which to negotiate with governments for greater international protections for displaced people.

${ }^{276}$ Burden-sharing has been a frequent theme of the High Commissioner's annual dialogues. For recent discussions, see United Nations High Commissioner for Refugees, International Cooperation to Share Burden and Responsibilities, June 2011, available at: http://www.refworld.org/docid/4e533bc02.html.

${ }^{277}$ See generally, Wyman, supra note 257. 


\section{Implementation}

A Displaced Persons Convention should be based on the principle of complementarity, providing legal protection to individuals only when their countries of origin are unable to provide it. Such a declaration of state incapacity can come from the state itself in a formal plea for international assistance, or by designation by the General Assembly or UNHCR that the state itself is incapable of providing for its citizens in a particular instance and that international assistance under the treaty is thereby required. The reputational costs of such a declaration of state incapacity would deter states from requesting international assistance unless it is necessary, and would incentive them to enact protections to avoid displacement in the first place. Convention protections might also be triggered by numbers of displaced people, such as a mass influx of 1,000 per day over a short time, which is unofficially used as UNHCR's criteria for mass influxes of refugees now. Alternatively, it could be triggered by numbers of people from a given country who have registered for services from UNHCR, or by a vote of the Security Council, General Assembly, or Convention signatory states that would determine whether a particular group of people met the definition of "Displaced People." Unlike its current practice, UNHCR must be required to publicize numbers of people registering for its services at various field offices so that the international community can become easily aware of flows of displaced people and act on them.

Despite the organization's flaws, UNHCR is best positioned to supervise a Displaced Persons Convention. As an international agency that has de facto been providing for the needs of much of this population for years, it has the expertise and the capacity to expand its operations to provide aid and administer new international law. Providing it with core funding for humanitarian use would insulate the Agency's activities from some of the politicization inherent in past humanitarian actions to assist refugees. With funding at the ready and the mandate to supervise a new international legal category, UNHCR would not have to wait to act to provide refugees or displaced people with protection and assistance until it received authorization from the U.N. or funding from a politically interested donor state.

All states participating in the Displaced Persons Convention, or in the fund mentioned above, should be required to recognize the 1951 Convention and its basic norm of non-refoulement. This would shore up protection for refugees by nations in the world who have an interest in receiving humanitarian assistance but who have previously been reluctant to sign the 1951 Convention. It would also ensure that international 
organizations and domestic legal systems alike are forced to understand the two separate categories of refugees and displaced persons and the differing protections that they will receive. Having the Refugee Convention as a prerequisite for the Displaced Persons Convention will ensure that the two documents are viewed as complementary to one another, and that countries do not lump displaced people and refugees together into one larger category that would undermine protections for both.

\section{Limitations of this Approach}

The reforms proposed here would improve protections for refugees, displaced people, and states alike. The improved doctrinal clarity would provide guidance to shape the behavior of states, individuals, U.N. Agencies, and NGOs within the international system while providing a stronger legal framework for the provision of humanitarian aid by the international community to those in need. It would make clear that persecution on the basis of religion, race, nationality, or membership in a particular social group is still among the most heinous of international crimes. Clarification that Convention refugees will receive priority in the international system for resettlement and assistance would reduce the processing burden on states and on UNHCR by discouraging people who do not meet these categories from applying. Those who still find it necessary to flee but who do not meet Convention grounds can be assured that they will receive temporary protection, and not summarily refouled to dire circumstances. States can be assured that they will have some control over who will reach their borders and to whom they will have to provide humanitarian aid, and a commitment to participate in a displaced persons regime will also enable states to plan to mitigate future displacement issues.

This solution, of course, will not solve all of the problems of the current international refugee regime. Desperate people will always flee desperate circumstances. Some politicization of the regime is inevitable; states providing oversight to a displacement regime may still decide to provide assistance to some people and not others on political grounds. The international community must carefully design such a system to reduce pull factors and an undue burden upon states. However, doctrinal clarity will help circumscribe the burdens on states and also clarify which displaced people will receive international assistance and which others would be better off seeking alternatives to flight abroad.

\section{CONCLUSION}

The dire humanitarian need engendered by forced displacement 
requires international action. However, additional legal protections for displaced people should not come at the expense of refugee protection. The current definition of refugee in international law is more important than ever. As international interventions are increasingly justified on humanitarian grounds, and states are increasingly willing to cede some of their sovereignty to international institutions, it is worth revisiting the principles that animated the creation of international refugee law to begin with. The protection of minority rights was a goal of international law even before the modern international human rights regime was born. Some of the earliest efforts at international protection of human rights were aimed at the protection of individuals who were persecuted by their states on the basis of political opinion, or who were unable or unwilling to be protected by states based on their religion, race, ethnicity, or membership in a particular social group. The core value of protecting these people became renamed, crystallized, entrenched, and reaffirmed in the international refugee regime as we know it today.

As perennial debates about the permissibility of violating state sovereignty to protect human rights have again resurfaced, an examination of international refugee law reveals when states have always been willing to yield sovereignty to protect human rights. The existence of international refugee law affirms the existence of core values of international human rights law that exist beyond the bounds of sovereignty. The wide acceptance of international refugee law, and especially of non-refoulement as a jus cogens norm, tells us that states are willing to cede some of their sovereignty to protect human rights, and have been since long before the development of the modern human rights regime. The rights of members of minority groups are so important that, for centuries, states have been willing to cede some of their sovereign right to determine who may enter and leave their borders to protect them. An examination of international refugee law reveals that certain values exist even outside the bounds of national law, and that those values must lie at the core of any universal human rights law for today's world. The international community cannot roll back or water down protections for refugees by expanding the definition of "refugee" because the core values that the refugee regime protects are too important and foundational to our very conception of what international human rights is. If every displaced person were a refugee, as other commentators would have it, then protection of bona fide refugees, and minority protections that are fundamental to our human rights regime, would be lost. Put simply, if everyone is a refugee, than no one is.

More generally, international refugee law sheds light on the fundamental question of the role of the individual as a subject of international law. The protection of the individual in international law has 
long been the subject of heated scholarly debate. ${ }^{278}$ In an international system based on sovereignty, states are the primary subject of international law. International law is made by states to regulate the behavior of states. However, international refugee law is an affirmation by the community of nations that states owe duties to individuals who are not their own citizens. The existence of refugee law suggests that states have legal duties to people beyond the borders of their own political community, and beyond the boundaries where their own laws can reach. States agreed to this basic notion that individuals fleeing persecution deserve some basic legal protections long before the modern conception of an international community of nation-states came to be. Refugee law reflects a cosmopolitan notion that wherever one flees, he will retain some basic rights and duties as citizens of the world. ${ }^{279}$ Those who support the ideals of a liberal international community bound by common respect for fundamental freedoms must take refugee protections seriously.

The protection of minorities is foundational to the democratic ideals to which the international community aspires. Refugee rights, which represent minority rights on an international scale, must therefore be preserved. While the world is not the same as it was in 1951, the lessons of World War II should still animate the international human rights regime today. Prevention of the evils that the Nazis perpetrated remains a yardstick against which to measure the effectiveness of human rights protections. As John Hart Ely eloquently argued,

It's not good enough to answer that the Holocaust couldn't happen here. We can pray it couldn't, I believe it couldn't, but nonetheless we should plan our institutions on the assumption that it could .... A regime this horrible is imaginable in a democracy only because it so quintessentially involved the victimization of a discrete and insular minority. ${ }^{280}$

International refugee law responds to Nazi atrocities by protecting minorities from persecution, whomever today's perpetrator may be, or wherever in the world they may flee. By adding displaced persons to those who receive international protection, states can affirm their commitment to cooperating to solve international humanitarian problems. By continuing to uphold the distinctive rights of refugees, the world can continually affirm that the systematic persecution of minorities will never occur again.

${ }^{278}$ See, e.g., LAUTERPACHT, supra note Error! Bookmark not defined..

${ }^{279}$ On cosmopolitanism and law, see Noah Feldman, Cosmopolitan Law?, 116 YALE L.J. 1022 (2007).

${ }^{280}$ ELY, supra note 33, at 181-82. 
International refugee law provides that human rights know no borders, moving us one step closer to a world in which universal human rights can be realized. 